\title{
Potential conflict between future development of natural resources and high-value wildlife habitats in boreal landscapes
}

\author{
Nobuya Suzuki ${ }^{1} \cdot$ Katherine L. Parker $^{1}$
}

Received: 15 January 2016/Revised: 9 September 2016/Accepted: 24 September 2016/

Published online: 21 October 2016

(C) The Author(s) 2016. This article is published with open access at Springerlink.com

\begin{abstract}
We used the Muskwa-Kechika Management Area in northeast British Columbia, Canada as a case study to determine potential conflicts between future resource development and high-value habitats of large mammals in an undeveloped boreal landscape. More than $50 \%$ of high-value habitats for caribou, moose, elk, wolves and grizzly bears were located in Special Resource Management Zones, where natural resource developments could occur. We developed geographic information system (GIS) layers of potential forest resources, oil and gas, minerals, wind power, all resources combined, and roads; and quantified the proportions of high-value habitats overlapping these potentials. Greater proportions of high-value habitats across seasons for moose, elk, and wolves overlapped areas with high cumulative resource potential (winter, 49-70\%, growing season, 35-63\%) more than for three other species (grizzly bears, Stone's sheep, mountain goats). This pattern was similar for forest resources, oil and gas, wind power, and roads. Caribou were more seasonally influenced. The proportions of their high-value habitat in areas with high cumulative resource potential (winter, $53 \%$, growing season, $16 \%$ ), as well as high forest and oil and gas potentials, were greatest in winter; in contrast, overlap with high mineral potential was greatest during the growing season. We recommend a quantitative and visual GIS approach to scenario planning in the Muskwa-Kechika to maintain the abundance and diversity of wildlife populations there. Resource development would likely
\end{abstract}

Communicated by Karen E. Hodges.

Electronic supplementary material The online version of this article (doi:10.1007/s10531-016-1219-2) contains supplementary material, which is available to authorized users.

Nobuya Suzuki

nobi.suzuki@unbc.ca

1 Natural Resources and Environmental Studies Institute, University of Northern British Columbia, 3333 University Way, Prince George, BC V2N 4Z9, Canada 
increase early seral habitats, presumably benefiting moose, elk, and wolves, but could adversely affect caribou and grizzly bears through habitat loss and increased access.

Keywords Boreal forest - British Columbia - Habitat conservation · Muskwa-Kechika Management Area · Resource development · Woodland caribou

\section{Introduction}

Conservation of intact ecosystems to sustain populations of species and biodiversity has become increasingly urgent as the human population worldwide continues to increase, seeking room for expansion into previously undeveloped wild lands and new opportunities for extraction of natural resources to satisfy ever increasing demands (Wittemyer et al. 2008; Leroux and Kerr 2013; Geldmann et al. 2014). This is particularly the case for Canada's boreal zone, where $25 \%$ of the world's intact forests, the largest surface area of wetlands on earth, and viable populations of large ungulates and large carnivorous mammals coincide with the presence of valued natural resources for human use (Badiou et al. 2013; Wells et al. 2013). For a long time, boreal lands were protected from resource development because of harsh climate, remoteness, and inaccessibility (Andrew et al. 2012, 2014). Now, cumulative effects from increasing development of multiple resources, such as timber, oil and gas, hydroelectric dams, and mining, have begun to alter compositions of biological communities largely because of habitat loss (Venier et al. 2014). Among wildlife in Canada's boreal zone, population declines and range contractions are pronounced for woodland caribou (hereafter caribou: Rangifer tarandus caribou) and grizzly bears (Ursus arctos); some populations have been extirpated near the southern border of the boreal zone (Venier et al. 2014).

Despite the ongoing threats to biodiversity from various resource developments, current status of ecosystem health in the boreal zone has not been assessed fully because long temporal and broad spatial biological and ecological datasets as well as coordinated research efforts are lacking (Kreutzweiser et al. 2013). It is, therefore, difficult to determine thresholds of ecological and biological sustainability against cumulative effects and to forecast future conditions of ecosystems and biodiversity (Venier et al. 2014). The threat of climate change and efforts to reduce greenhouse gasses have encouraged development of green energy in the boreal region (Kreutzweiser et al. 2013). Development of wind power has intensified where large tracts of lands are available for construction of wind towers (Bright et al. 2008; Roscioni et al. 2013). Such effects of green energy development on wildlife are yet to be fully understood (Kuvlesky et al. 2007; Bright et al. 2008; Lovich and Ennen 2011). Although there are large tracts of undeveloped, contiguous natural habitats still remaining in the boreal zone of western Canada in Yukon and northern British Columbia (Carroll et al. 2003, 2004; Pearce et al. 2008), wildlife habitats within boreal and sub-boreal areas are highly susceptible to disturbance because productive lands are smaller in proportion to those in temperate zones to the south and can be targets of resource development. Conservation of habitats to sustain viable populations of species requires much larger areas of protection and connectivity in the boreal and sub-boreal zones than would be required in temperate zones (Carroll et al. 2004).

Within the boreal zone of western Canada, areas encompassing the northern Rocky Mountain region in northern British Columbia have been identified as irreplaceable 
contiguous habitats of high conservation value for bird diversity (Pearce et al. 2008) and the secure source needed to sustain viable populations of carnivores. Populations of grizzly bears, for example, are in decline and isolated from one another farther south in British Columbia and the US, where lands are increasingly developed (Carroll et al. 2003, 2004). Contiguous habitats are also critical in the conservation of woodland caribou, for which populations are declining across their geographic range (McLoughlin et al. 2003; Wittmer et al. 2007; Latham et al. 2011). Adverse effects of industrial development for oil, natural gas, and forest resources may have already exceeded the threshold of recovery for some caribou populations and habitats (Sorensen et al. 2008; Komers and Stanojevic 2013).

We present a proactive approach to assess probable conflicts between areas with high potential for natural resource development and wildlife habitats in a large boreal landscape with high conservation value for wildlife and with little history of industrial development. We used the Muskwa-Kechika Management Area (hereafter referred to as the MuskwaKechika), which is 6.4 million ha of rare contiguous wild land the size of Ireland in northeast British Columbia, as a case study area to examine potential consequences of multiple resource developments on habitats of seven large-mammal species. Although almost no industrial resource development has occurred in the area, conflicts in the future between habitat conservation and industrial resource development are highly likely, given that the area supports a large-mammal assemblage with some of the highest species diversity and abundance in North America (Shultis and Rutledge 2003; Locke 2010). The Muskwa-Kechika is recognized as a secure source for declining populations of species at the continental scale of North America (Carroll et al. 2003, 2004) and as part of irreplaceable contiguous natural habitats with high biological value (Pearce et al. 2008). The area also is known for its potential of abundant renewable and non-renewable natural resources, including forest resources, oil, natural gas, minerals, and wind power (Fort Nelson LRMP Working Group 1997; Fort St. John LRMP Working Group 1997; Mackenzie LRMP Working Group 2000; British Columbia Ministry of Sustainable Resource Management 2004; Snively and Brumovsky 2011). Outside of the MuskwaKechika in northeast British Columbia, cumulative effects of multiple natural resource developments have altered the distribution of wildlife habitats, reduced the amount of lateseral habitats, and increased early seral communities (Nitschke 2008). Habitat quality is projected to decline for focal wildlife species in the region over the coming decades (Strimbu and Innes 2011).

Our first objective was to quantify current levels of habitat protection for seven largemammal species in the Muskwa-Kechika by comparing the proportions of high-value habitat for each species across seasons among designated land zones with varying restrictions for industrial development. In particular, our intention was to quantify the amount of high-value habitat in existing provincial parks, ecological reserves, and protected areas compared to that in areas of possible resource development. Our second objective was to quantify levels of resource potential in high-value habitats of each of the seven species across seasons to visually and quantitatively highlight areas of high-value habitat that are potentially vulnerable to resource development. This analysis also provides a baseline of current conditions in the Muskwa-Kechika and sets the stage for scenario planning for development that minimizes impacts to wildlife.

We discuss potential outcomes of future resource development on these large-mammal species by comparing and contrasting differences among species relative to measures of multiple resource potential and road potential, and relative to four industrial resourcespecific potentials. Among the four industrial resources, we assumed development of forest resources and oil and gas, once initiated, would more likely spread across the landscape 
and have extensive impacts on wildlife habitats than development for mining and wind power, which would tend to cluster and affect smaller areas. We expected that high-value habitats of caribou and grizzly bears, species reported as particularly sensitive to resource development, would overlap areas with high potential for multiple natural resources and road development in greater proportions than would the high-value habitats of other species. Furthermore, we expected that high-value habitats of these two sensitive species would overlap more with high potentials for forest resources and oil and gas, at least during part of the year, than for other resources. Moose (Alces alces) and elk (Cervus canadensis), two species of ungulates often associated with early seral stages of forests, and wolves (Canis lupus), their primary predator, are widely distributed across the landscape. The high-value habitats of these three species would likely overlap areas with high potential for forest resources and oil and gas depending on distributions of those resources on the landscape. In contrast to the two sensitive and three more generalist species, we presumed the high-value habitats associated with the rocky slopes of montane habitats at high elevations all year round for Stone's sheep (Ovis dalli stonei) and mountain goats (Oreamnos americanus), would overlap areas with high mineral and wind power potential more than high forest resource or oil and gas potential. In addition, relative to wind power potential specifically, we surmised that the habitats of caribou in gentle alpine slopes, where strong winds are common, could overlap areas with high wind power potential in greater proportions than those of all other species.

\section{Materials and methods}

\section{Study area}

In the southwest corner of the boreal region in northeast British Columbia lies the Muskwa-Kechika Management Area (Fig. 1). Apart from the Alaska Highway crossing the northeast corner of the Muskwa-Kechika, access is limited to horse and hiking trails, several government-sanctioned all-terrain vehicle trails (also used for some snowmobiling in winter), and some riverboat travel. There has been a long history of human activity by First Nations (Shultis and Rutledge 2003; Heinemeyer et al. 2004). Almost no industrial activity has occurred in the area.

The large-mammal assemblage in the Muskwa-Kechika includes caribou, moose, elk, Stone's sheep, mountain goats, mule deer (Odocoileus hemionus), white-tailed deer (Odocoileus virginianus), American bison (Bison bison), black bears (Ursus americanus), grizzly bears, wolves, and wolverines (Gulo gulo). The northern ecotype of woodland caribou in the Muskwa-Kechika is of particular concern for conservation in British Columbia because 15 of 31 herds of this ecotype in the province are listed as threatened under Canada's federal Species at Risk Act (British Columbia Conservation Data Centre 2015).

The Muskwa-Kechika is intended to conserve and maintain diversity of wildlife and their habitats, integrity of ecosystems, and wilderness quality in perpetuity, but some portions of the Muskwa-Kechika also are designated to accommodate consumptive and non-consumptive human use, including recreation, hunting, trapping, timber harvesting, mining, and oil and gas exploration and development in accordance with the MuskwaKechika Management Area Act of 1998 (British Columbia Government 1999). To achieve these diverse goals of ecological, social, and economic sustainability, lands of the 
(a)

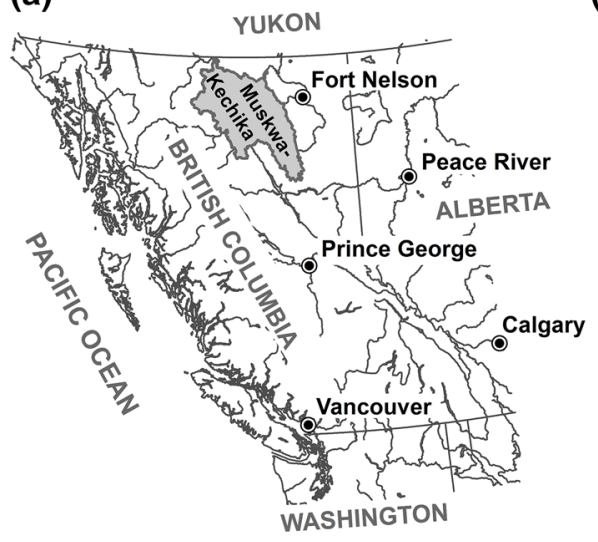

(b)

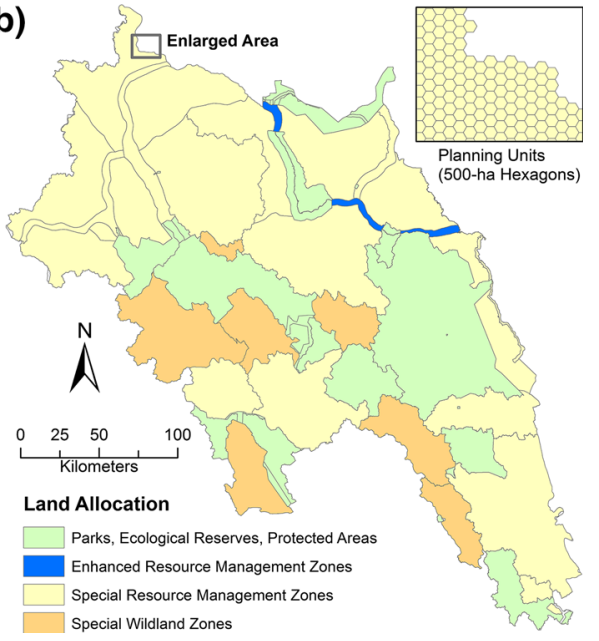

Fig. 1 Location of a the Muskwa-Kechika Management Area (Muskwa-Kechika), and b the land allocation within it, and planning units in 500-ha hexagons covering the entire land area of the Muskwa-Kechika, northeast British Columbia, Canada. Resource development is allowed in Special Resource Management Zones and Enhanced Resource Management Zones; timber harvesting is prohibited but other resource development is allowed with strict operational restrictions in Special Wildland Zones, and natural resource development is not allowed in provincial parks, ecological reserves, and protected areas (Protected Area Zones)

Muskwa-Kechika are designated into one of four zones: (1) Protected Area Zone, (2) Special Wildland Zone, (3) Special Resource Management Zone, and (4) Enhanced Resource Management Zone (Fig. 1b) (Heinemeyer et al. 2004; Muakwa-Kechika Management Area 2014). Protected Area Zones, including provincial parks, ecological reserves, and protected areas, were established to maintain ecological values as well as cultural and recreational values. Resource development activities are prohibited in these areas. Special Wildland Zones were designated to maintain ecological, wilderness, and recreational values. In these areas, timber harvest is prohibited but development for minerals with non-road exploration or temporary access roads may be permitted. Development for oil and gas, while not prohibited in Special Wildland Zones, is unlikely to occur because these areas are mostly to the west of the Western Canada Sedimentary Basin where land-based oil and gas developments in western Canada have occurred (Schneider et al. 2003). Special Resource Management Zones allow commercial recreation and industrial activities along with construction of access corridors, such as temporary roads, across the zones. Construction of permanent roads is allowed in some areas within Special Resource Management Zones. Areas around the Alaska Highway Corridor were designated as Enhanced Resource Management Zones, which have the least restrictions for industrial resource development, but also encourage development for recreation and tourism (Muskwa-Kechika Management Area 2014).

\section{Assessment of current levels of habitat protection in the Muskwa-Kechika}

We determined high-value habitats for seven focal species-caribou, moose, elk, Stone's sheep, mountain goats, wolves, and grizzly bears-using models developed by Heinemeyer et al. (2004) for habitat suitability based on species' habitat needs and ecological 
requirements. Their models were verified with field data and they made adjustments to improve model performance (Heinemeyer et al. 2004). All models were used to rate sitespecific vegetation and topographic characteristics following provincial modeling recommendations. For all species except grizzly bears, there were two habitat models-one for the growing season (spring-fall) and the other for winter. For grizzly bears, there were three habitat models - early-growing season (spring), mid-growing season (summer), and late-growing season (fall). All habitat suitability models were designed to produce habitat suitability scores ranging from 0 for the lowest suitability to 100 for the highest suitability for 50-m pixels across large ecoregions encompassing the Muskwa-Kechika (Heinemeyer et al. 2004). To generate habitat suitability scores for the Muskwa-Kechika at the spatial scale of 500-ha planning units (Fig. 1b) for each species and season, we averaged scores of 50 -m pixels for each planning unit, which consisted of approximately 2000 50-m pixels. We ranked all planning units across the Muskwa-Kechika according to percentiles (1-100) of habitat suitability scores among planning units and assigned planning units in the top 30 percentiles as high-value habitat for a species in a particular season (Online Resource 1: Figs. S1.1, S1.2, S1.3). Our intention in distinguishing the top 30 percentiles of habitat suitability was to provide a realistic minimum target value that is practical for conservation planning for the high-value habitats of the seven species. Because planning units are identical in area, designated high-value habitat based on the top 30 percentiles covered $30 \%$ of the area of the Muskwa-Kechika. However, areas of high-value habitat for species and by season differed among land zones of the Muskwa-Kechika, which varied in levels of protection.

To determine current levels of habitat protection for the seven large-mammal species listed above, we compared the proportions of high-value habitats for each species across seasons among (1) Protected Area Zones, where no natural resource development is allowed, (2) Special Wildland Zones, where the areas are largely protected but allow limited resource development, and (3) Special Resource Management Zones, where areas are open to resource development with fewer operational restrictions. In our analyses hereafter we included Enhanced Resource Management Zones as part of the Special Resource Management Zones because Enhanced Resource Management Zones only cover a minor fraction of the Muskwa-Kechika (Fig. 1b) and have a scope similar to Special Resource Management Zones relative to resource development.

\section{Developing GIS layers of resource and road potential}

To assess areas of possible conflict between future resource development and habitat conservation, we used ArcGIS 10 (ESRI 2011) and developed the following six raster layers of resource potential (Figs. 2, 3): forest resource potential, oil and gas potential, mineral potential, wind power potential, cumulative resource potential, and resource potential diversity. These six layers were intended to indicate where resources are most likely to be targeted for development based on resource potential across the MuskwaKechika in relation to general distributions of natural resources. In addition, we created a geographic information system (GIS) layer of road potential to indicate the relative feasibility of road development in the Muskwa-Kechika (Fig. 3c).

We used vegetation resource inventory data (British Columbia Ministry of Forests, Lands and Natural Resource Operations, Forest Analysis and Inventory Branch 2013) to develop the raster layer of forest resource potential by integrating the four forest stand variables that are routinely used to assess timber production: site index, basal area, quadratic mean diameter, and live stand volume (Online Resource 2). The resource 


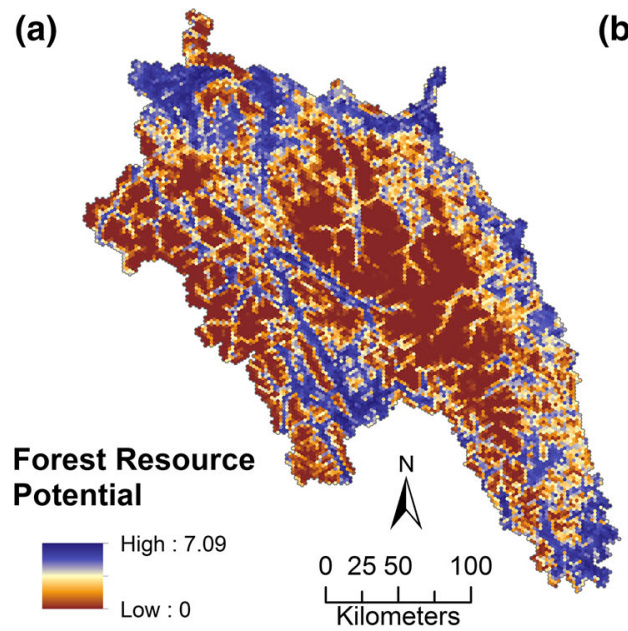

(b)

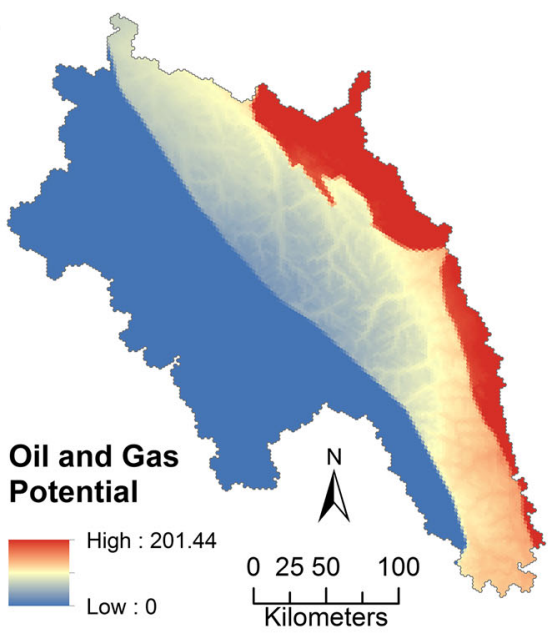

(c)

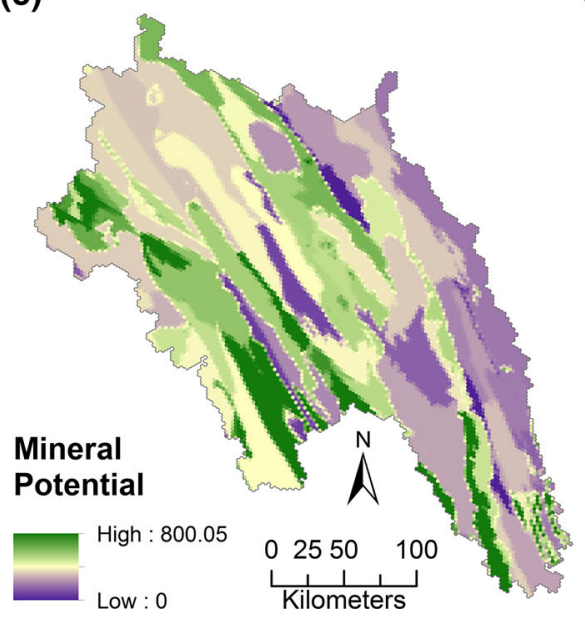

(d)

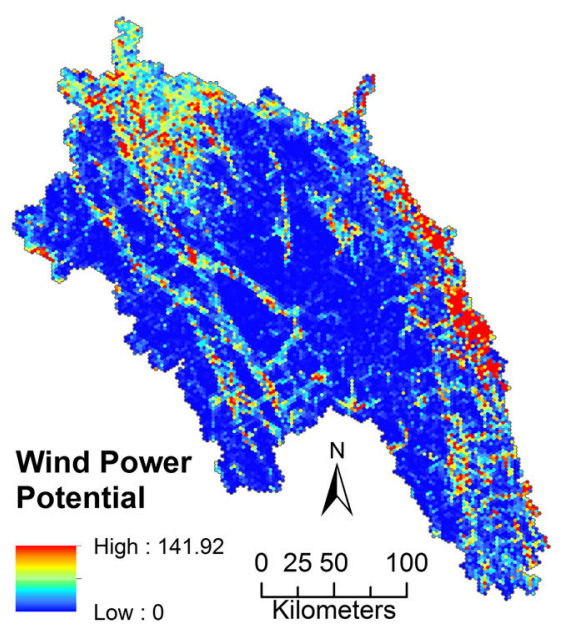

Fig. 2 Geographic information system (GIS) raster layers of a forest resource potential, b oil and gas potential, c mineral potential, and $\mathbf{d}$ wind power potential; these spatial data indicate where resources are most likely to be targeted for development based on resource potential across the landscape in the MuskwaKechika Management Area, northeast British Columbia, Canada

potential layer for oil and gas was developed by integrating spatial data on oil and gas geology, conventional natural gas inventory, oil and gas resource sites, tenures, gas pipelines, and elevation (Online Resource 3). The mineral potential layer was derived from spatial data from British Columbia government sources, including province-wide mineral potential, coal geology, mineral tenures, and mineral occurrence (Online Resource 4). We developed the layer of wind power potential by assessing and integrating spatial data on wind speed and direction, topographic characteristics, and locations of wind power tenure and existing power lines (Online Resource 5). Our development of the road potential layer was based on the assessment and integration of relative physical feasibility of road development; relative impact distance, which is a measure of proximity to existing manmade features that likely have some potential for encouraging road development; and 

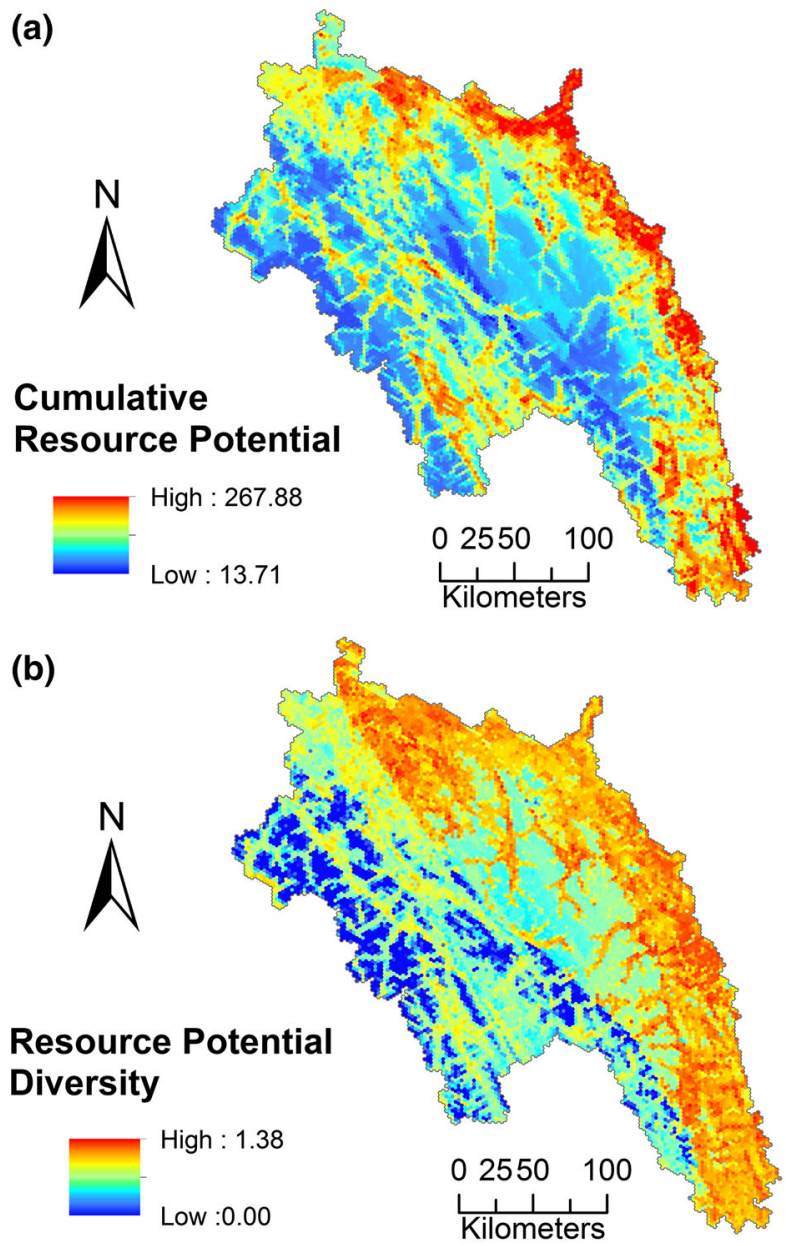

(c)

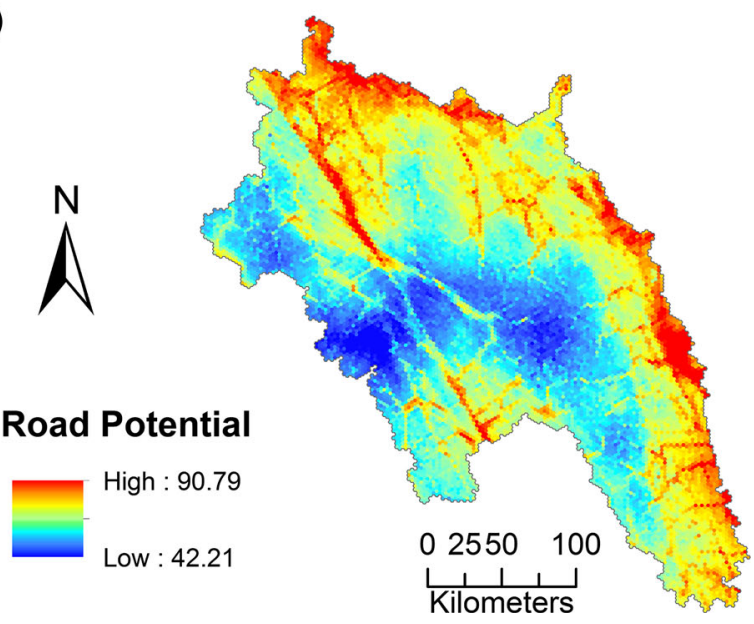


Fig. 3 Geographic information system (GIS) raster layers of a cumulative resource potential (the combined potential of forest resources, oil and gas, minerals, and wind power), $\mathbf{b}$ resource potential diversity (potential presence of diverse types of resources), and c road potential (locations of potential road development) in the Muskwa-Kechika Management Area, northeast British Columbia, Canada

density of wetlands or lakes, which may act as an obstacle to road development where density is too high (Online Resource 6).

We created a raster layer of cumulative resource potential across the Muskwa-Kechika (Fig. 3a) by summing raster layers of oil and gas potential, forest resource potential, mineral potential, and wind power potential (Fig. 2) at the 500-ha planning unit scale. When summing values among resource potentials of these four resources, we used percent of the maximum original value among planning units for each resource as the common unit among the four resources. This layer is intended to provide a spatial distribution for the total potential of all these resources combined. Similarly, we combined the values of the same four resource-specific potentials (with percent of the maximum original value as the unit), using the Shannon diversity index (Magurran 1988) to create a raster layer of resource potential diversity in the planning units (Fig. 3b). The higher the value of resource potential diversity, the more variety of resources with high potential values is expected; with low value of resource potential diversity, fewer different resources with lower potential values in a planning unit are expected.

We assumed that development of natural resources would likely occur initially in areas with the highest resource potential and expand into areas with the next highest available resource potential. In reality, development would probably expand into adjacent areas with successively lower resource potential until it was no longer economically profitable. However, cost and benefit analysis for the economic thresholds of development is beyond the scope of our study. Therefore, we assumed that areas in the top third (top 30 percentiles) of resource potential in the Muskwa-Kechika are most likely to be targeted for resources. Those top 30 percentiles of resource potential, however, include areas that are protected from development (Protected Area Zones) and/or areas with strong regulations on development (Special Wildland Zones), as well as areas where resource extraction is permitted (Special Resource Management Zones). Hence, in our analyses related to impacts on wildlife we excluded areas that are unlikely or less likely to be developed and focused on the overlap with resource potential in Special Resource Management Zones.

\section{Assessment of conflict between resource development and habitat conservation}

We spatially compared the high-value habitat layers (top 30 percentiles) for each of the seven focal species by season with resource potential layers at the planning unit scale (500 ha) to determine potential areas of conflict. To better assess the levels of resource potential within high-value habitats, we created 10 classes of resource potential for each resource potential type (4 individual resource sector potentials as well as cumulative and diversity potentials and road potential) by dividing the resource potential values into intervals of 10 percentiles [class 1 (1-10th percentile), class 2 (10-20th percentile), etc.]. We refer to 1-30th percentiles (classes 1-3) as low resource potential, 30-70th percentiles (classes 4-7) as medium resource potential, and 70-100th percentiles (classes 8-10) as high resource potential.

For each species across seasons, we tabulated areas intersecting high-value habitats and each class of resource-potential ranking, and then calculated the percent area of high-value 
habitat overlapping areas in the 10 classes of each resource potential type within Special Resource Management Zones. We assumed that conflicts are most likely to occur when high-value habitat coincides with high-value (top 30 percentiles) resource potential. We also determined what $\%$ area of the entire Muskwa-Kechika includes high resource potentials in Special Resource Management Zones for the seven resource potential types; and what $\%$ area has high resource potentials overlapping high-value seasonal habitats for the seven species. We created maps of high-value habitats of species overlapping the percentile classes of resource potentials to aid in conservation and management planning for wildlife habitat and natural resources in the Muskwa-Kechika.

\section{Results}

\section{Contributions of designated areas to high-value wildlife habitat}

Special Resource Management Zones, where the highest levels of resource development activities are allowed in the Muskwa-Kechika, included more high-value habitats, across seasons, for the seven species of large mammals analyzed than did the Special Wildland Zones or Protected Area Zones (provincial parks, ecological reserves, and protected areas; Fig. 4). More than half of the area identified as high-value habitat for five species (caribou, moose, elk, wolves, and grizzly bears) across seasons was located in the Special Resource Management Zones. In comparison, Protected Area Zones, where development of natural resources is not allowed, encompassed $<30 \%$ of the high-value habitats across seasons for these five species. Slightly more than $30 \%$ of high-value habitats for Stone's sheep (growing season, $37 \%$, winter habitat, $37 \%$ ) and mountain goats (growing, $34 \%$, winter, $35 \%$ ) were in Protected Area Zones. The Special Wildland Zones, where limited resource

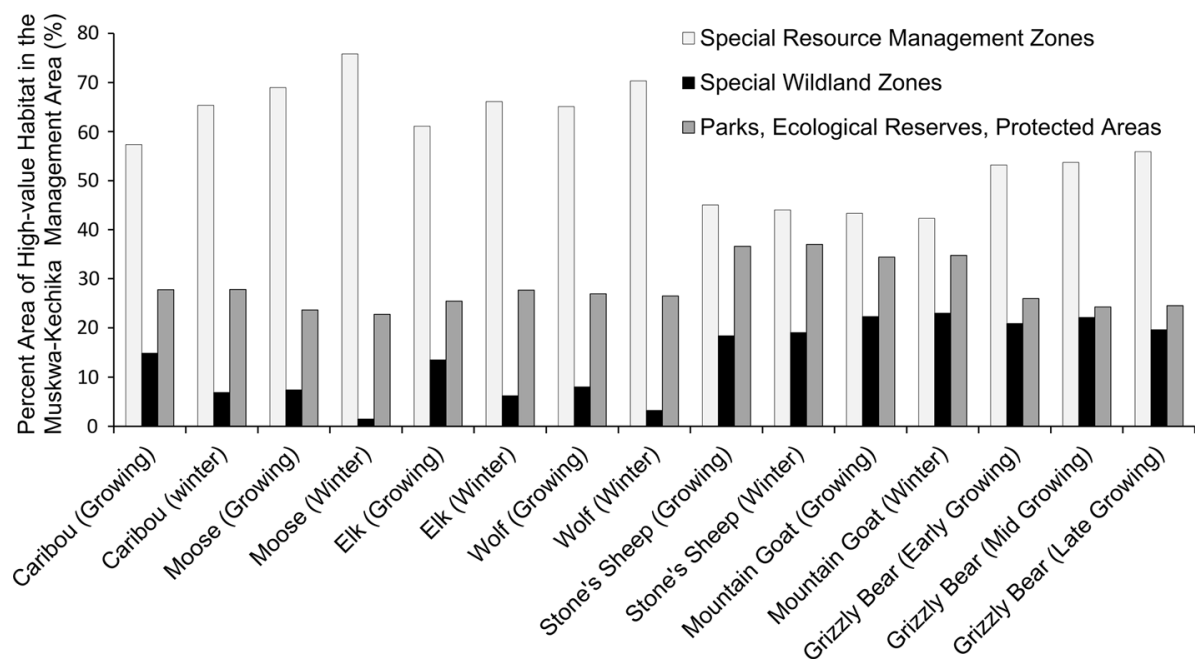

Fig. 4 Percent area of high-value habitats for seven large mammal species, compared among Special Resource Management Zones, Special Wildland Zones, and Protected Area Zones (parks, ecological reserves, and protected areas) across seasons in the Muskwa-Kechika Management Area, northeast British Columbia, Canada 
development activities (excluding forestry) are allowed, encompassed $<25 \%$ of highvalue habitats for all seven species across seasons.

\section{Cumulative resource potential, resource potential diversity, and road potential in special resource management zones}

Areas with high cumulative resource potential, high resource potential diversity, and high road potential (defined to be in the top 30 percentiles of the Muskwa-Kechika) in Special Resource Management Zones accounted for 21, 21, and $23 \%$ of the land area of the Muskwa-Kechika, respectively (Online Resource 7: Table S7.8). Areas of these three high
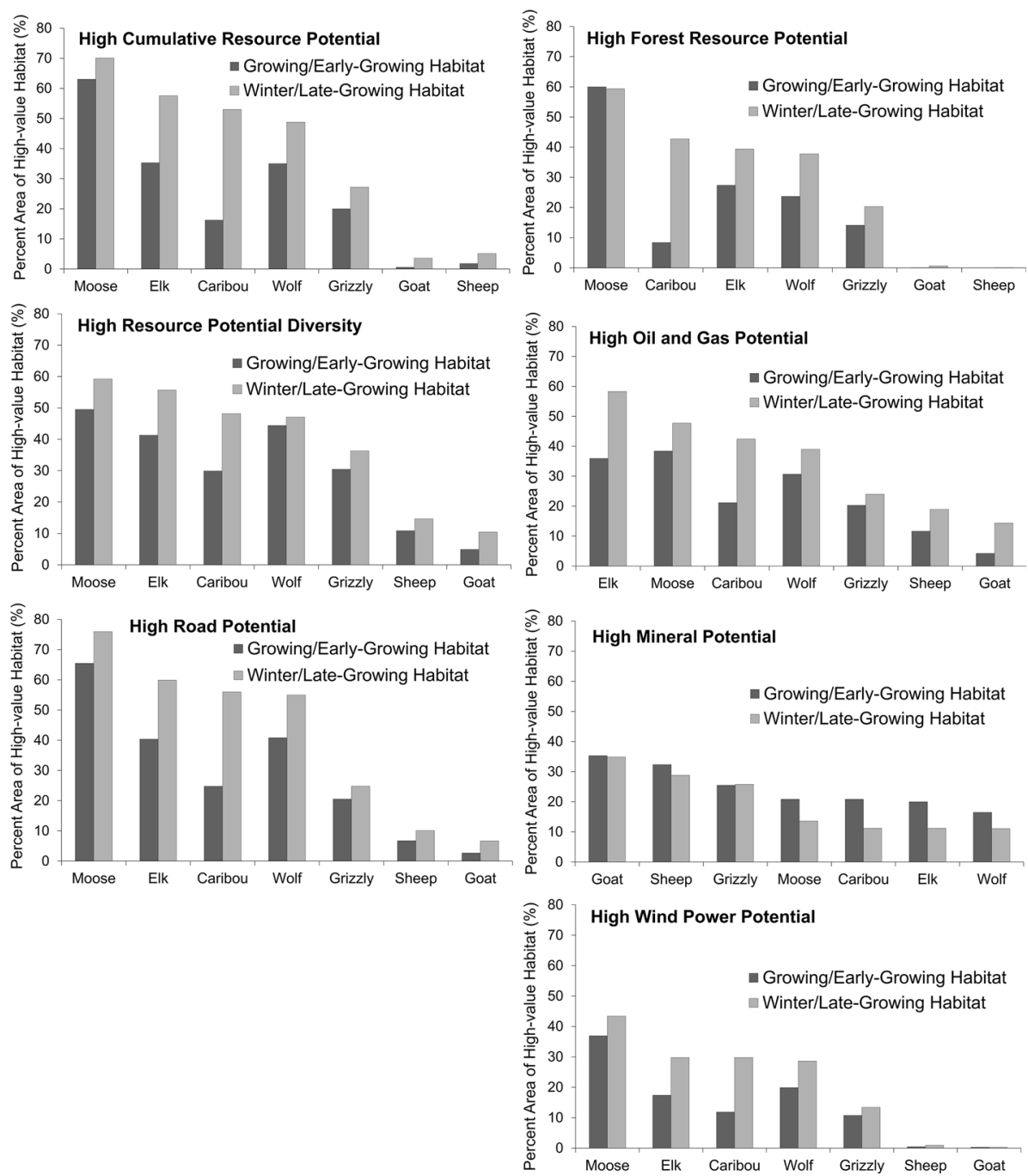

Fig. 5 Percent area of high-value habitats for seven large mammal species overlapping areas with high potential for six measures of natural resources as well as for road feasibility, compared across seasons and species, in Special Resource Management Zones of the Muskwa-Kechika Management Area, northeast British Columbia, Canada 

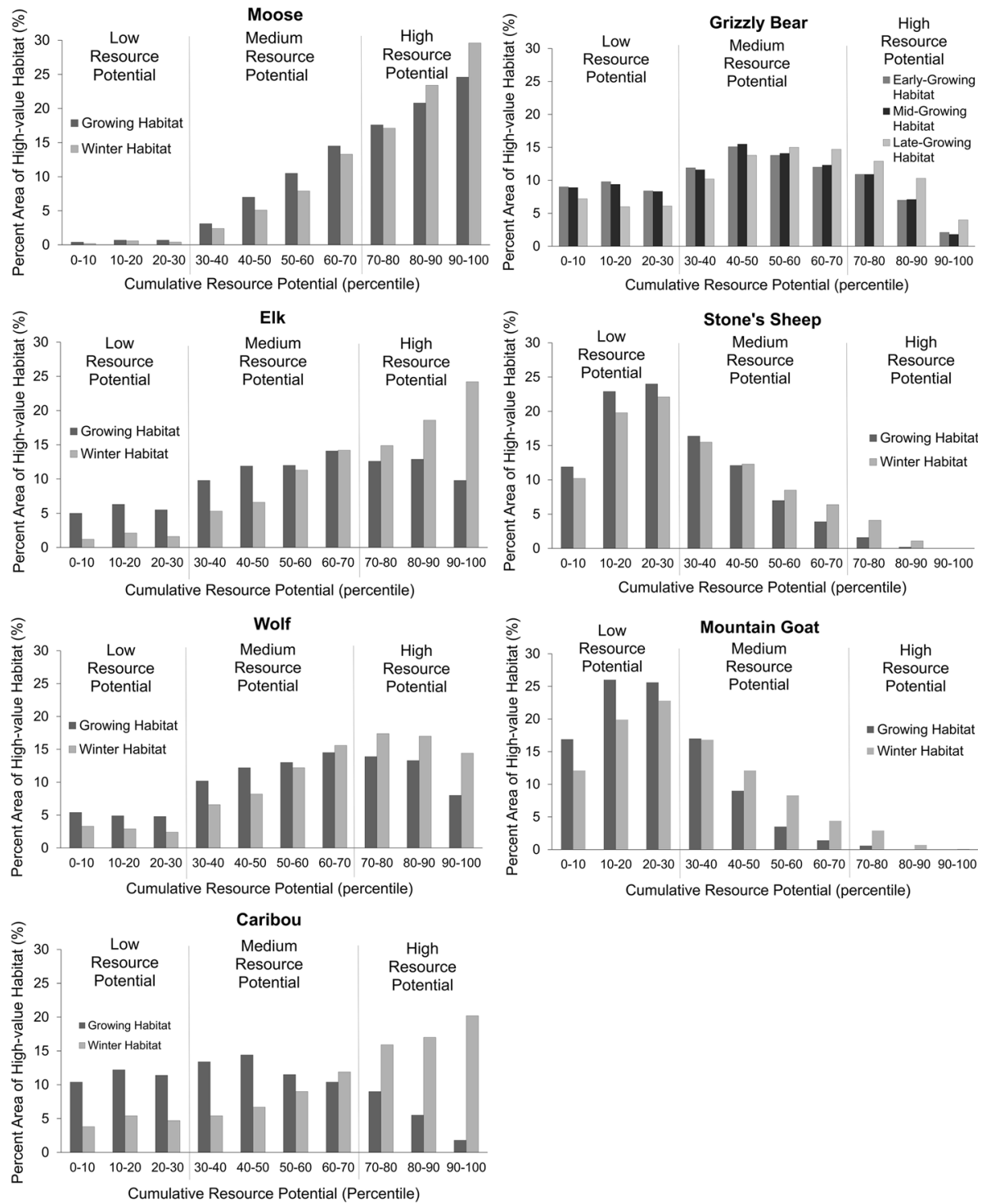

Fig. 6 Percent area of high-value seasonal habitats for seven large mammal species within 10-percentile classes of cumulative resource potential ranked as low, medium, or high cumulative potential, in Special Resource Management Zones of the Muskwa-Kechika Management Area, northeast British Columbia, Canada. We refer to the lowest percentiles as low resource potential, the 30th-70th percentiles as medium resource potential, and the top 30 percentiles as high resource potential

potentials intersected the high-value habitats in Special Resource Management Zones most for moose in winter and least for mountain goats and Stone's sheep across seasons, occurring on 13-17 and $<2 \%$ of the Muskwa-Kechika land base, respectively (Online Resource 7: Table S7.9). 

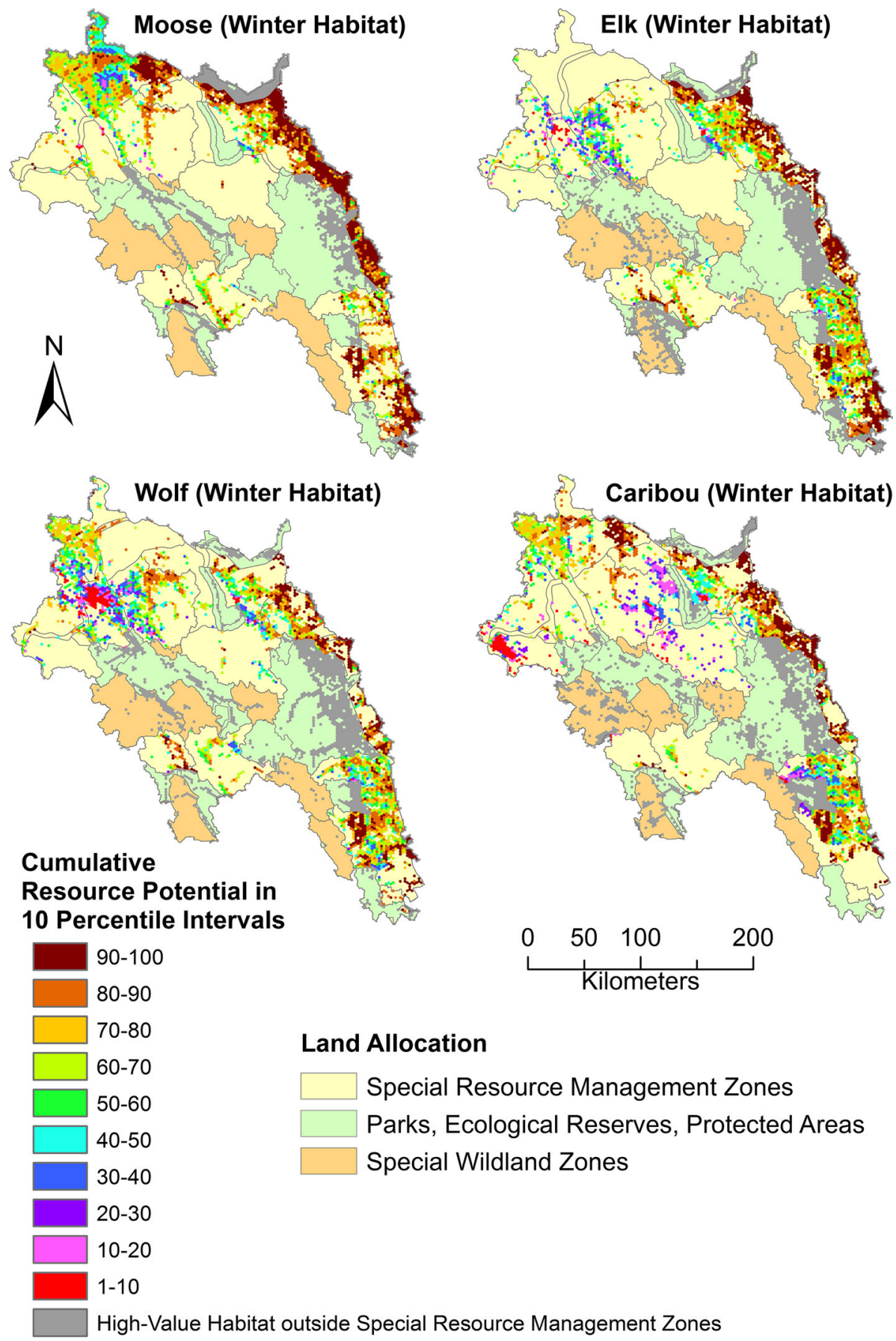

Fig. 7 Cumulative resource potential in percentiles from 1 (lowest) to 100 (highest) within high-value habitats for moose, elk, wolves, and caribou in Special Resource Management Zones of the MuskwaKechika Management Area, northeast British Columbia, Canada. These species-season combinations showed highest overlap between high-value habitats and cumulative resource potential 

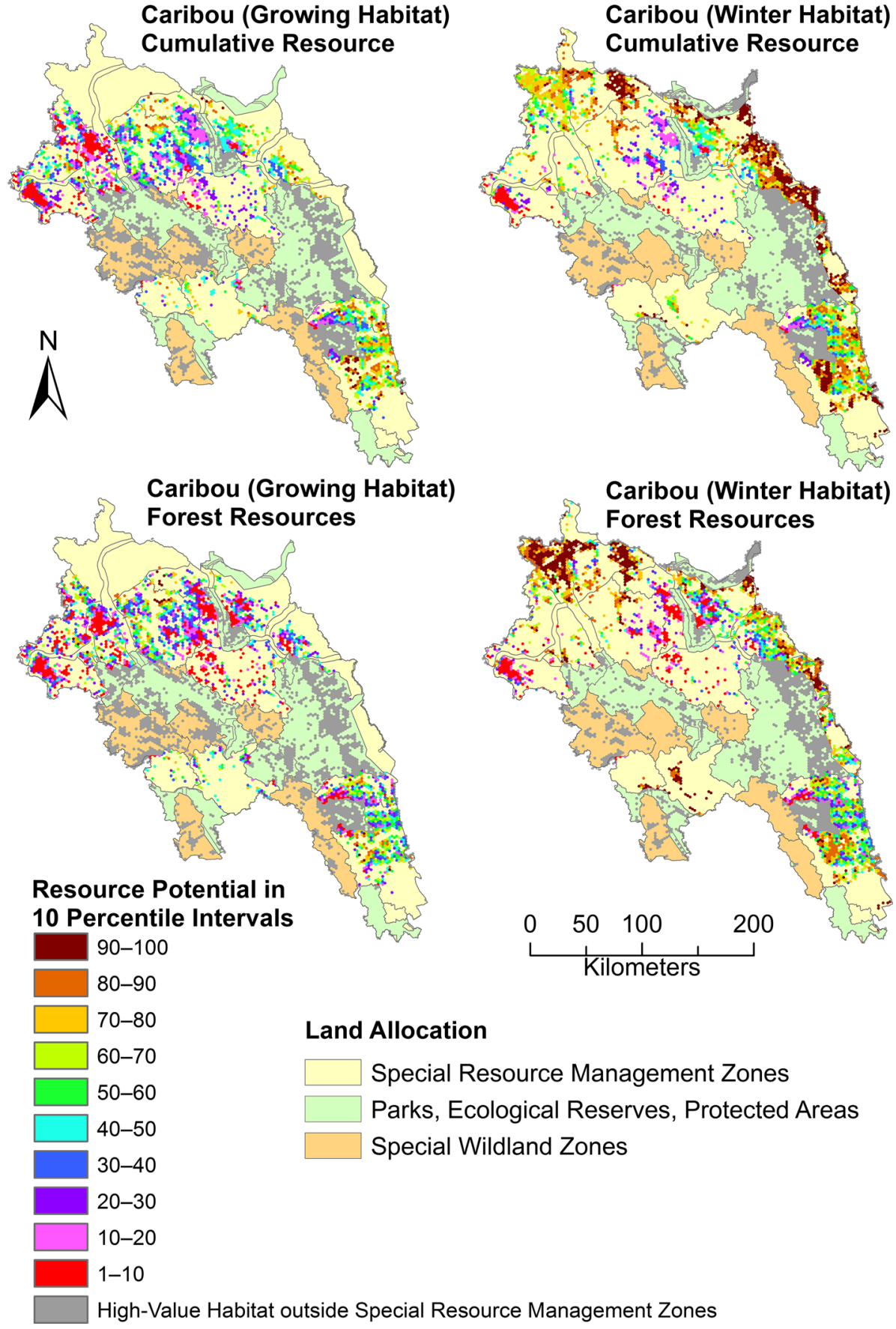

Caribou (Winter Habitat)
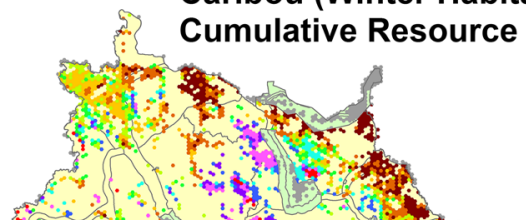

Het
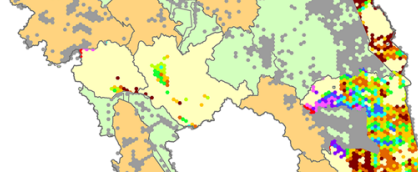

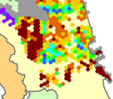

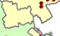

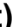


TFig. 8 Seasonal comparison of cumulative resource potential and forest resource potential within highvalue growing and winter habitats for caribou in Special Resource Management Zones of the MuskwaKechika Management Area, northeast British Columbia, Canada. Resource potentials are shown in percentiles from 1 (lowest) to 100 (highest). Areas of high cumulative and forest resource potential (top 30 percentiles) overlapped more high-value habitat for caribou in winter than in the growing season

\section{Cumulative resource potential}

Areas with high cumulative resource potential occurred most frequently along the eastern boundary of the Muskwa-Kechika (Fig. 3a). They overlapped large proportions ( $>30 \%)$ of the high-value habitats across seasons for moose (growing season, $63 \%$, winter, $70 \%$ ), elk (growing, $35 \%$, winter, $57 \%$ ), and wolves (growing, $35 \%$, winter, $49 \%$; Fig. 5: high cumulative resource potential; Figs. 6, 7; Online Resource 7: Table S7.1). Areas of high cumulative resource potential also occurred in a large proportion of the high-value winter habitat for caribou (53\%), which was more than three times the overlap with high-value growing habitat (16\%; Fig. 8). The proportion of high-value habitat for grizzly bears in areas of high cumulative resource potential was lower across seasons (early-growing, $20 \%$, mid-growing, $20 \%$, late-growing, $27 \%$ ) than for moose, elk, or wolves. Only $\leq 5 \%$ of the high-value habitats for mountain goats (growing, $1 \%$, winter, $4 \%$ ) and Stone's sheep (growing, $2 \%$, winter, $5 \%$ ) occurred in areas with high cumulative resource potential.

\section{Resource potential diversity}

The general pattern for high resource potential diversity in high-value habitats across species was similar to that for high cumulative resource potential (Figs. 3b, 5: high resource potential diversity; Online Resource 7: Table S7.2, Online Resource 8: Fig. S8.1). Areas with high resource potential diversity overlapped large proportions of high-value habitats for moose (growing season, $50 \%$, winter, $59 \%$ ), elk (growing, $41 \%$, winter, $56 \%$ ), wolves (growing, $44 \%$, winter, $47 \%$ ), and caribou. The proportion of high-value habitat of caribou in areas with high resource potential diversity was 1.6 times higher in winter $(48 \%)$ than in the growing season $(30 \%)$, although the difference was smaller than that for cumulative resource potential. Similarly, this overlap for grizzly bears was greater in the late-growing season (36\%) than in the early (30\%) or mid-growing seasons (30\%). Areas with high resource potential diversity occurred in relatively small proportions of high-value habitats for Stone's sheep (growing, $11 \%$, winter, $15 \%$ ) and mountain goats (growing, $5 \%$, winter, $10 \%$ ) compared to other species.

\section{Road potential}

Areas with high road potential overlapped a greater proportion of high-value habitats for moose (growing season, $65 \%$, winter, $75 \%$ ) than other species (Fig. 5: high road potential, Online Resource 7: Table S7.3, Online Resource 8: Fig. S8.2), although overlaps with highvalue habitat for elk (growing, $40 \%$, winter, $60 \%$ ) and wolves (growing, $41 \%$, winter, $55 \%)$ were also high across seasons. Again for caribou, the proportion of high-value habitat with high road potential was highest in winter (56\%, growing, $25 \%$ ). Areas of high road potential overlapped smaller proportions (20-24\%) of the high-value habitats for grizzly bears than for moose, elk, caribou, or wolves. Less than about $10 \%$ of high-value habitats 
for mountain goats (growing, $3 \%$, winter, $7 \%$ ) and Stone's sheep (growing, $7 \%$, winter, $10 \%$ ) occurred in areas with high road potential.

\section{Resource-specific potentials in Special Resource Management Zones}

\section{Forest resource potential}

Areas of high forest resource potential overlapped approximately $60 \%$ of high-value habitat across seasons for moose, the highest among the seven species (Fig. 5: high forest resource potential, Online Resource 7: Table S7.4, Online Resource 8: Fig. S8.3). For caribou, $43 \%$ of high-value habitat in winter occurred in areas with high forest resource potential, which was more than five times that in the growing season $(8 \%)$. Proportions of high-value winter habitats for elk (39\%) and wolves (38\%) overlapping areas of high forest resource potential were only slightly lower than for caribou. However, the overlap in the growing season for elk ( $27 \%)$ and wolves $(24 \%)$ was about three times higher than for caribou. Compared to moose, elk, and wolves, proportions of high-value habitats occurring in areas with high forest resource potential were lower for grizzly bears (early-growing, $14 \%$, mid-growing, $15 \%$, late-growing, $20 \%$ ). The high-value habitats of mountain goats and Stone's sheep across seasons did not overlap $(<1 \%)$ areas with high forest resource potential.

\section{Oil and gas resource potential}

Areas of high oil and gas potential overlapped the largest proportion of high-value habitats across seasons for elk (growing season, $36 \%$, winter, $58 \%$ ), followed by moose (growing, $38 \%$, winter, $48 \%$ ) and wolves (growing, $31 \%$, winter, $39 \%$; Fig. 5: high oil and gas potential, Fig. 10, Online Resource 7: Table S7.5, Online Resource 8: Fig. S8.4). The overlap with $42 \%$ of the high-value habitat for caribou in winter was the third highest among the seven species, and was double the overlap in the growing season $(21 \%)$. Areas of high oil and gas potential also occurred in high-value habitats for grizzly bears, Stone's sheep, and mountain goats in greater proportions in winter and fall than in the growing season (Stone's sheep: growing, $12 \%$ and winter, $19 \%$; grizzly bears: early-growing, $20 \%$, mid-growing, $18 \%$, and late-growing, $24 \%$; mountain goats: growing, $4 \%$ and winter, $14 \%$ ), although these levels were relatively low.

\section{Mineral potential}

Areas of high mineral potential coincided with the largest proportion of high-value habitats across seasons for mountain goats (growing season, $35 \%$, winter, $35 \%$ ), followed by Stone's sheep (growing, $32 \%$, winter, $29 \%$ ) and grizzly bears (early-growing, $25 \%$, midgrowing, $26 \%$, late-growing, $25 \%$; Fig. 5: high mineral potential, Online Resource 7: Table S7.6, Online Resource 8: Fig. S8.5). Overlap was lower for moose (growing, $21 \%$, winter, $14 \%$ ), caribou (growing, $21 \%$, winter, $11 \%$ ), elk (growing, $20 \%$, winter $11 \%$ ), and wolves (growing, $17 \%$, winter, $11 \%$ ). For these latter four species, overlap was consistently higher in the growing season than in winter, a pattern opposite of the overlaps with areas of high oil and gas potential and high forest resource potential. 


\section{Wind power potential}

Areas of high wind power potential across seasons occurred in the greatest proportion of high-value habitat for moose (growing season, $37 \%$, winter, $43 \%$ ), followed by elk (growing, $17 \%$, winter, $30 \%$ ), caribou (growing, $12 \%$, winter, $30 \%$ ), and wolves (growing, $20 \%$, winter, $29 \%$; Fig. 5: high wind power potential, Online Resource 7: Table S7.7). For all of these species but especially elk and caribou, more overlap occurred in winter than in the growing season. Overlaps with high-value habitat for grizzly bears from spring to fall were smaller (early-growing, $11 \%$, mid-growing, $11 \%$, late-growing, $13 \%)$ than those of moose, elk, caribou, and wolves, and very little overlap $(<1 \%)$ occurred for mountain goats and Stone's sheep.

In Special Resource Management Zones, areas with high resource potential for forest resources, oil and gas, minerals, and wind power accounted for 17, 14, 15, and $13 \%$, respectively, of the land area of the Muskwa-Kechika (Online Resource 7: Table S7.8). The area of each of the high resource potentials that also coincided with high-value habitat within Special Resource Management Zones was highest for moose in winter, when the overlap with forest resources, oil and gas, and wind power comprised 13, 11, and $10 \%$ of the Muskwa-Kechika land base, respectively (Online Resource 7: Table S7.10). Highest overlap for mineral potential was with the high-value habitats of mountain goats and Stone's sheep during the growing season on $4 \%$ of the Muskwa-Kechika area.

\section{Comparison among industrial resource sectors for overlap with high-value habitats of individual species}

For elk and wolves, the proportion of high-value habitat overlapping high industrial potential was highest in areas of high oil and gas potential, followed by areas of high forest resource potential, and then wind power potential across seasons (Figs. 9, 10). The overlap was least with areas of high mineral potential for wolves across seasons and for elk in winter. For moose, high-value habitat overlapped most with high forest resource potential, followed by oil and gas and wind power; overlap was again lowest in areas with high mineral potential. For caribou, seasonal differences were much more apparent. In winter, high-value habitat overlapped most, at similar levels, with areas of high forest resource potential and oil and gas potential, followed by areas with high wind power potential (Figs. 9, 11). In contrast, in the growing season, almost twice the proportion of high-value habitat, relative to that in winter, overlapped areas of high mineral potential, and less than half the proportions of high-value habitat (relative to winter) overlapped areas of high potential for oil and gas, forest resources, and wind power.

For Stone's sheep, mountain goats, and grizzly bears, the highest proportions of highvalue habitats across seasons overlapped areas with high mineral potential followed by oil and gas potential. The high-value habitat of grizzly bears also overlapped areas with high forest resource potential, particularly in the late-growing season, and overlap with high wind power potential was the lowest among the four industrial resource sectors. There were very little overlap between the high-value habitats of Stone's sheep and mountain goats and areas of high wind power or forest resource potentials. 

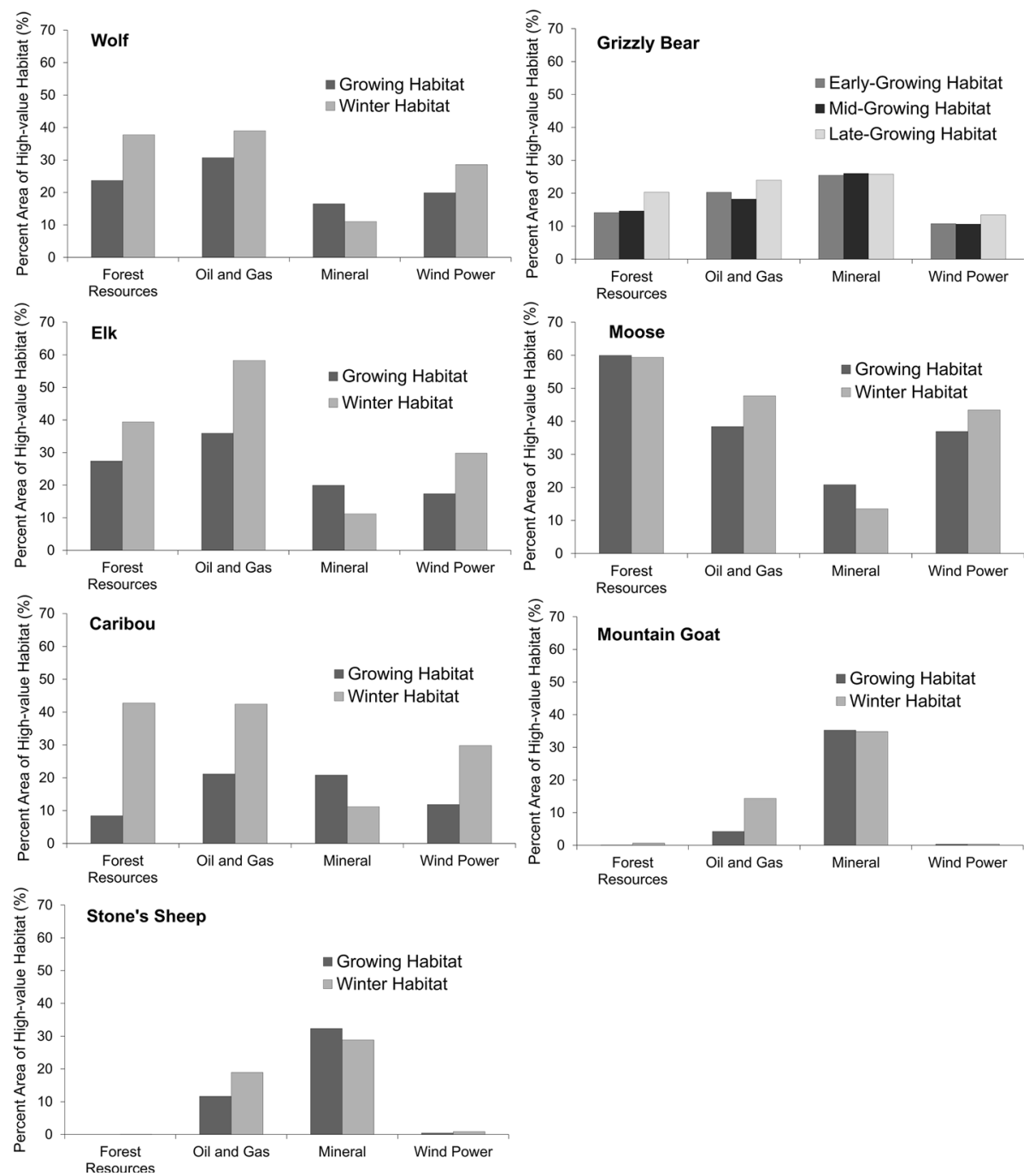

Fig. 9 Percent area of high-value seasonal habitats for seven large mammal species with high potential for industrial resources (forest resources, oil and gas, minerals, wind power) in Special Resource Management Zones of Muskwa-Kechika Management Area, northeast British Columbia, Canada

\section{Discussion}

\section{Cumulative resource potential and resource potential diversity in high-value habitats}

The extent of conflict between developing resources and maintaining wildlife populations in the Muskwa-Kechika will vary depending on resource potentials in areas of high-value habitat and the ecology of different species. Contrary to our expectation, the proportions of high-value habitats of caribou and grizzly bears overlapping areas with high cumulative resource potential and resource potential diversity were not the highest among the seven 

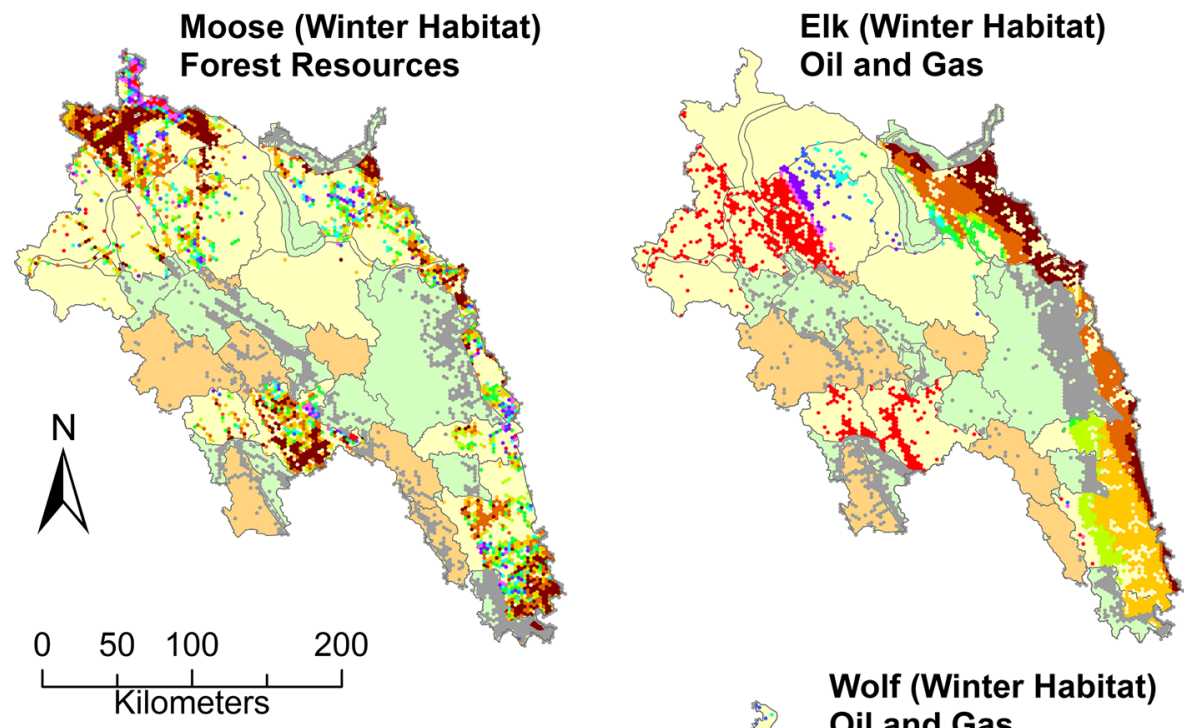

\section{Resource Potential in 10 Percentile Intervals}

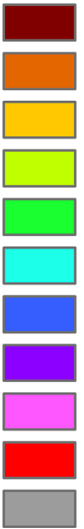

90-100

$80-90$

$70-80$

60-70

50-60

40-50

Land Allocation

$30-40$

20-30

10-20

Special Resource Management Zones

Wolf (Winter Habitat)

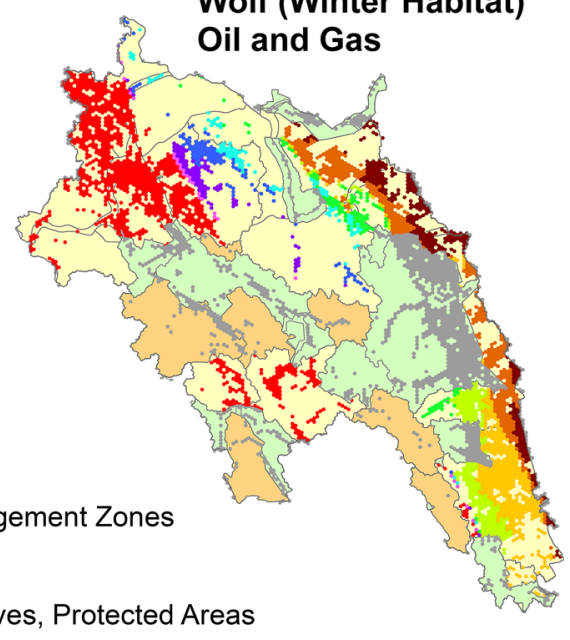

$1-10$

High-Value Habitat outside Special Resource Management Zones

Fig. 10 Resource potentials in percentiles from 1 (lowest) to 100 (highest) for selected industrial resources within high-value habitats for moose, elk, and wolves in Special Resource Management Zones of the Muskwa-Kechika Management Area, northeast British Columbia, Canada. For each species, the sectorspecific resource (forest resources, oil and gas, minerals, or wind power) with the most overlap between high resource potential (top 30 percentiles) and high-value seasonal habitats (growing season or winter) is shown

species. Instead, across seasons, overlaps were consistently highest for moose followed by elk or wolves depending on season and the measure of multiple resource potential. Moose, elk, and wolves are habitat generalists whose occurrence across landscapes is more ubiquitous than that of the other four species we examined (Munõz-Fuentes et al. 2009; Stewart et al. 2010; Brodie et al. 2012). Consequently, broadly distributed high-value habitats of these three species increased the likelihood of their overlap with areas of high cumulative resource potential and high resource potential diversity. 

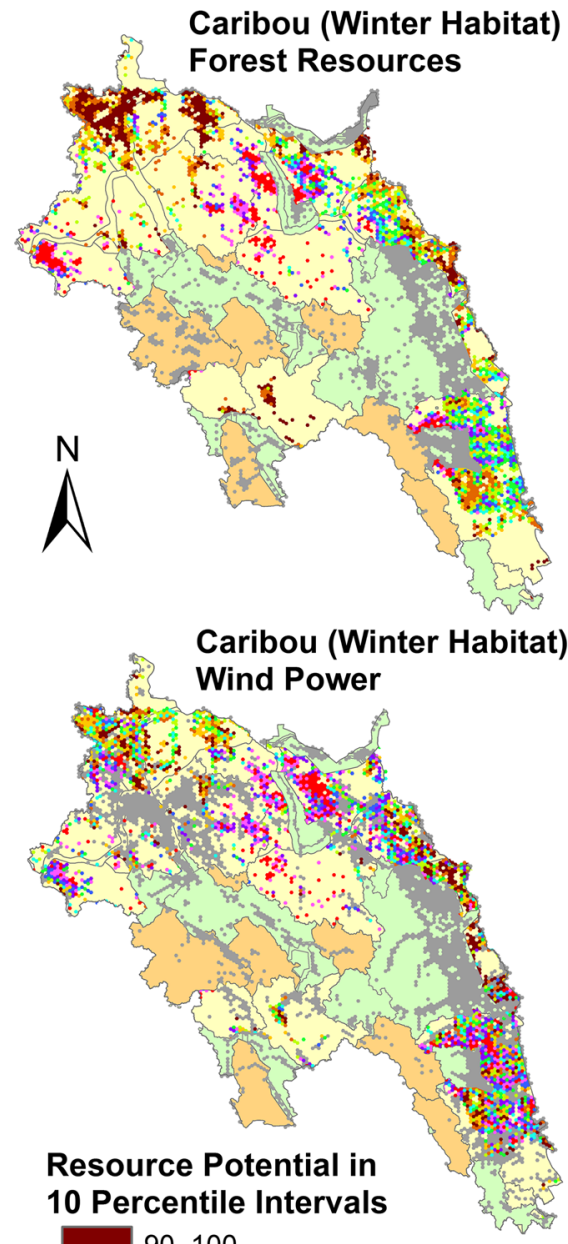
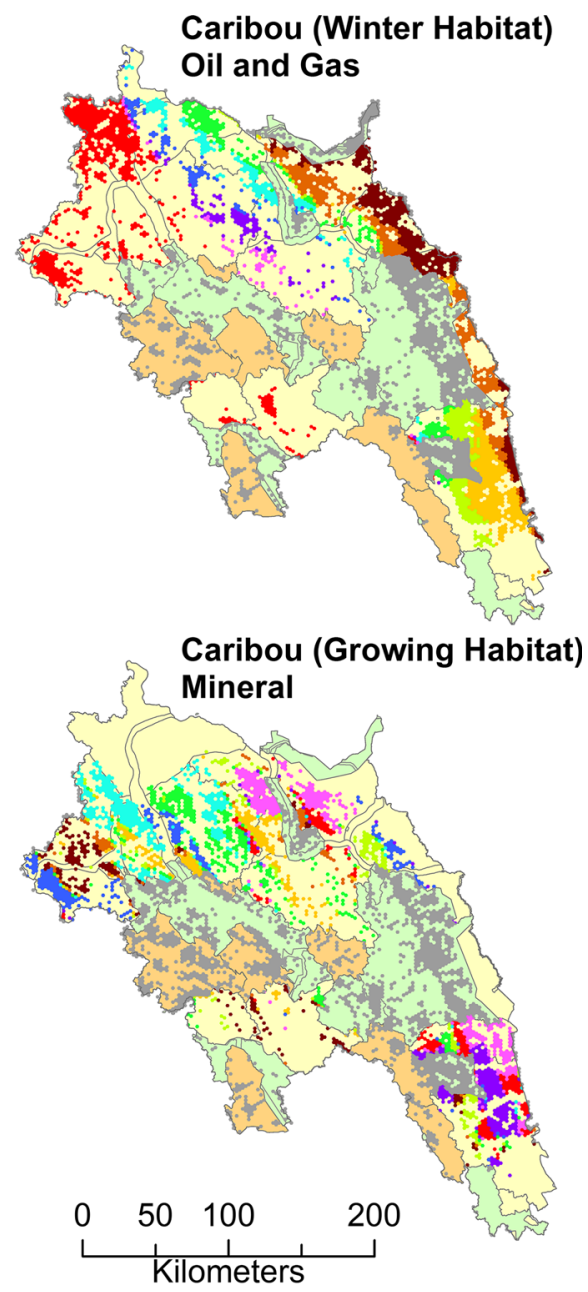

Land Allocation

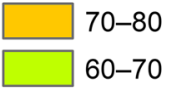

$\square 50-60$

$\square 40-50$

$30-40$

20-30

10-20

$1-10$

High-Value Habitat outside Special Resource Management Zones
Special Resource Management Zones

Parks, Ecological Reserves, Protected Areas

Special Wildland Zones

Overlap between high-value habitats and measures of multiple resource potential can vary markedly between seasons, for caribou in particular. Caribou typically spend much of the growing season in high alpine areas, where the cumulative resource potential and resource potential diversity are relatively low because the potential for developing oil and 
4Fig. 11 Resource potentials in percentiles from 1 (lowest) to 100 (highest) for industrial sector-specific resources within high-value habitat for caribou in Special Resource Management Zones of the MuskwaKechika Management Area, northeast British Columbia, Canada. Areas with high potential (top 30 percentiles) for forest resources, oil and gas, and wind overlapped more high-value habitat for caribou in winter than in the growing season. In contrast, areas with high potential for minerals occurred most frequently in high-value growing habitats

gas and forest resources is low. For caribou that overwinter in lower elevation habitats (Seip 1992; Johnson et al. 2004; Gustine and Parker 2008), the potential for developing forest resources as well as oil and gas is higher than in alpine areas and is reflected in higher cumulative resource potential and resource potential diversity in their winter habitat. Similarly, the overlap between high-value habitat for grizzly bears and cumulative resource potential and resource potential diversity is greatest during the late-growing season when the bears use lower elevations than during spring in the Muskwa-Kechika (Milakovic et al. 2012).

Impacts of overlapping high-value habitat and exploitation of high resource potentials beyond the immediate short term are variable. Habitat alterations resulting in an increase in early seral communities can benefit species (e.g., moose, elk, wolves) that are also tolerant of some industrial development (James et al. 2004; Dunne and Quinn 2009; Houle et al. 2010; Webb et al. 2011; Van Dyke et al. 2012). In contrast, the large overlap between highvalue winter habitat and areas of resource activity is of particular concern for the conservation of woodland caribou because as a species at risk (Committee on the Status of Endangered Wildlife in Canada 2011), it is highly sensitive to resource development. Caribou populations across Canada have drastically declined where resource development has occurred (Vors et al. 2007; Seip 2008; Sorensen et al. 2008; Boutin et al. 2012). Grizzly bears often are not adversely affected directly from resource development in the short term (McKay et al. 2014; McLellan 2015), but can be adversely affected by the increase in human presence and activities that result from long-term cumulative effects of resource development across broad landscapes (Apps et al. 2004; Linke et al. 2005; Ciarniello et al. 2007; McLellan 2015). Contrasting with wide-ranging species such as caribou and grizzly bears, Stone's sheep and mountain goats show strong fidelity to small specific areas. Overlap with industrial activity in these critical parts of seasonal ranges would have substantive negative consequences even if, as we determined, there was not extensive overlap with their highest value habitats. Both species of high mountain ungulates are highly susceptible to overhead disturbance that may occur during any exploratory or extraction activities (Frid 2003; Côté et al. 2013).

In addition to the direct consequences that could result from developing cumulative resource potential and diversity in high-value habitats, access into the Muskwa-Kechika via roads to develop and extract resources would probably negatively affect all populations of large-mammal species over time. The proportion of high-value habitats overlapping areas with high potential for road development was greatest for moose, followed by elk or wolves depending on season. Mortality from hunting or other fatal encounters with humans tends to increase in populations of moose (Rempel et al. 1997), elk (Unsworth et al. 1993; McCorquodale et al. 2003), wolves (Person and Russell 2008), and grizzly bears (McLellan 2015) in response to improved road access for humans into remote areas. When road density is high, predation risk to caribou calves increases in disturbed landscapes (Dussault et al. 2006). Roads also affect movements of mountain sheep and goats to seasonal ranges, which may reduce gene flow and genetic diversity, and preclude access to traditional mineral licks (Epps et al. 2005; Poole et al. 2010). 


\section{Responses of large-mammal species to potential resource-specific developments}

At broad landscape scales over time, fragmentation of contiguous landscapes by industrial development into scattered early seral patches with long edge habitats could enhance populations of moose and elk (Irwin and Peek 1983; Schneider and Wasel 2000; Leclerc et al. 2012 b) and consequently their primary predators, particularly wolves, in the MuskwaKechika (James et al. 2004; Sorensen et al. 2008). Caribou then could be subjected to higher predation pressure (Seip 1992). Moose have strong affinity to early seral forests and forest edges (Proulx and Kariz 2005; Leclerc et al. 2012b), whereas elk, also an early seral ungulate, tend to use more diverse habitats including open meadows and grasslands, as well as forest stands (Poole and Mowat 2005; Rumble and Gamo 2011). The relatively high forest resource potential that we observed in high-value habitats of these two ungulate species (as expected), indicates that their habitats in the Muskwa-Kechika could be altered from forest management activities. Forest harvesting creates early seral habitats dominated by graminoids and forbs, which increase in abundance for approximately 10 years and then gradually decline over the next $\sim 30$ years (Visscher and Merrill 2009). Populations of elk, with a preferred forage base of graminoid vegetation (Jenkins and Starkey 1993; Christianson and Creel 2007), would benefit initially. Moose, which forage primarily on shrubs (Stewart et al. 2010), would benefit most in approximately 10-15 years after harvest once shrubs began to increase (Potvin et al. 2005; Leclerc et al. 2012b). The gradual increase in shrub biomass over time would continue to support moose populations for 30-40 years following timber harvesting (Proulx and Kariz 2005; Leclerc et al. 2012b).

The overlap between high-value habitats of wolves and areas with high potential for forest resources as well as for oil and gas in the Muskwa-Kechika was consistently lower in proportion than those of their ungulate prey-moose and elk in the growing season and moose, elk and caribou in winter. Wolves tend to concentrate in forested landscapes fragmented with early seral habitat patches (Courbin et al. 2014) or naturally fragmented habitats with diverse vegetation types that increase the chances of encountering prey (Milakovic et al. 2011). The effects of industrial development, including oil and gas, forest resources, and wind power, on wolves appear to differ depending on type and density of industrial features and their associated human activity (Ehlers et al. 2014). Because wolves tend to avoid areas with high levels of human activity, presumably they would be displaced or forced to modify ranges and activity patterns if centers of development were established in the vicinity of currently occupied territories. On the other hand, wolves may benefit from sites of active development if some prey species, such as caribou, vacate disturbed areas and then concentrate in the periphery of developed areas in predictable patterns (Weir et al. 2007; Polfus et al. 2011). Moderate to high levels of high-value habitat of wolves in the Muskwa-Kechika overlapped areas with high resource potential for oil and gas, forest resources, and wind power; however, it is unlikely that wolf populations would be negatively affected directly from development activities of these resources, given there are thriving wolf populations on other landscapes heavily altered by industrial development (Schneider et al. 2010; Latham et al. 2011; Boutin et al. 2012).

Caribou are the ungulate species most likely to be affected by resource development and use in the Muskwa-Kechika. Large areas with high potential for forest resources, oil, and gas, as well as some areas with high potential for wind power coincided with high-value winter habitats. Areas with high mineral potential occurred more frequently in high-value growing habitats than winter habitats. These patterns suggest that oil and gas and forest 
resource activities could alter winter habitats at lower elevations. Development of wind power could affect caribou habitats across elevations, including wind-swept slopes in highelevation wintering areas, and development for minerals would alter growing habitats in high-elevation alpine areas. Vulnerability of caribou to industrial development of oil and gas has been well documented. In Alaska, USA, expansion of oil fields and associated infrastructure and roads reduced the abundance of calving barren-ground caribou $(R$. $t$. groenlandicus) by $72 \%$ (Joly et al. 2006). In Alberta, Canada, exploration and development for oil and gas have been a major contributing factor towards cumulative effects that are responsible for habitat loss and population declines of woodland caribou (Sorensen et al. 2008; Komers and Stanojevic 2013). Development activities can affect regular patterns of behavior and physiological conditions, increase movement rates and disrupt feeding cycles, increase energy expenditures and mass loss in winter, force caribou to alter traditional habitats, and decrease calf production and survival (Bradshaw et al. 1997, 1998). Consequently, caribou tend to avoid industrial features, especially when human activity levels are high (Dyer et al. 2001). Man-made linear corridors, including seismic lines, pipelines, roads and trails, often adversely affect caribou while benefitting wolves. These linear features facilitate access by wolves to otherwise inaccessible areas that historically served as natural refugia for caribou (James et al. 2004; Courbin et al. 2009; Latham et al. 2011), and increase predation rates (James and Stuart-Smith 2000), thereby contributing to population declines.

There are concerns relative to the conservation of lower elevation forests for wintering caribou because a large proportion of high-value winter habitats appears to overlap areas with high forest resource potential in the Muskwa-Kechika. Many woodland caribou (but not all; Gustine and Parker 2008) overwinter in large contiguous late-successional forests at lower elevation (Stronen et al. 2007; Hins et al. 2009). Alterations of these habitats would likely reduce biomass of ground and arboreal lichens, their primary winter forage (Seip 1998). In addition, habitat alterations are known to disrupt range fidelity (Faille et al. 2010) and reduce availability of winter refugia where caribou can segregate from predators and alternative prey (Seip 1992; James et al. 2004; Courbin et al. 2009). Caribou may be restricted to smaller remaining areas of suitable forest rather than spreading out at low density to avoid predators (Smith et al. 2000; Courtois et al. 2008; Lesmerises et al. 2013), or be forced to migrate long distances between late-successional forest blocks across a landscape with high predation risk (Johnson et al. 2002). Consequently, increases in predation rates, particularly by wolves (Dussault et al. 2012; Leclerc et al. 2012a, 2014), and reductions in survival rates often occur following extensive forest harvesting (Wittmer et al. 2007; Faille et al. 2010).

As with moose, elk, and wolves, the proportion of high-value habitat for caribou overlapping areas with high mineral potential was lower than for other resources. However, the overlap occurring in the growing habitat of caribou may pose a threat in high-elevation alpine areas because sensitivity of caribou to development activities is much higher than for moose, elk, or wolves. Relatively little has been documented regarding the effects of mining on woodland caribou, although it has been considered a threat to their conservation in northeast British Columbia (Muir and Booth 2012). In the Muskwa-Kechika, the potential for mining coal as well as metallic and industrial minerals coincided most with the high-value growing habitats of caribou. If resource extraction occurred, ground disturbance would directly reduce biomass of vascular plants and ground lichens in alpine and subalpine areas where many caribou spend their spring and summer. Caribou that overwinter on the windswept slopes of alpine areas also depend on ground lichens for their main source of winter forage (Seip 1998; Johnson et al. 2002, 2004). Recovery of this 
forage base would be slow (Smyth 1997). Because caribou tend to avoid mining sites by at least $2 \mathrm{~km}$ (Weir et al. 2007; Polfus et al. 2011), functional loss of habitat and reduction in forage available for caribou would be much greater than the losses attributed only to ground disturbed by mining.

Unlike the interactions among early seral ungulates (elk and moose), wolves, and caribou that are influenced strongly by changes in forest landscapes (cutblocks, oil and gas pads, and seismic lines), the high-value habitats of grizzly bears, Stone's sheep, and mountain goats are more likely to be altered by development of minerals than other resources. We did not expect a high proportion of high-value habitat for grizzly bears to overlap areas with high mineral potential in the Muskwa-Kechika. Our analyses indicated that mining could alter habitats of grizzly bears across seasons, although somewhat smaller habitat alterations would result from development of oil and gas and forest resources, particularly in their late-growing habitats. Little is documented about the effects of surface mining on habitat use and populations of grizzly bears. Industrial activities may affect selection of den sites, as bears tend to avoid human activities, including industrial development, when selecting their dens (Linnell et al. 2000; Pigeon et al. 2014). Human activities $<1 \mathrm{~km}$ away can cause some bears to abandon their dens and potentially increase cub mortality (Linnell et al. 2000). However, grizzly bears are adaptable to some changes in habitat conditions (Stewart et al. 2012). They may forage on older oil and gas well sites or in clearcuts with increased berry production, and development for oil, gas, and forest resources does not necessarily affect population size and other demographic features (McKay et al. 2014; McLellan 2015). Therefore, habitat alterations by industrial development, including mining, at fine spatial scales for individual projects may not have direct substantial adverse effects on populations of grizzly bears in the short term. Rather, the expansion of human activities and road access into remote areas across the MuskwaKechika over time, facilitated by mining as well as other industrial developments, would likely reduce bear numbers from hunting and bear-human conflicts (Ciarniello et al. 2007; McLellan 2015).

Not surprisingly, the high-value habitats of Stone's sheep and mountain goats in the Muskwa-Kechika overlapped areas with high potential for minerals in greater proportions than those of other resources and other species. Responses of these two mountain ungulates to development of minerals or other resources are largely undocumented. Among wild sheep closely related to Stone's sheep, Dall's sheep $(O . d$. dalli) and bighorn sheep $(O$. canadensis) regularly used reclaimed coal mining sites (Elliott and McKendrick 1984; MacCullum and Geist 1992) and bighorn sheep also used an active copper mining site (Jansen et al. 2006, 2007) and mineral licks created by drilling for natural gas (Morgantini and Bruns 1988; Morgantini and Worbets 1988). Mining sites can offer various benefits to wild sheep. For example, removal of trees and shrubs creates open habitat with little vegetative obstruction, which may change wind patterns and reduce snow depth (MacCullum and Geist 1992). Presence of human activities, which lower predation risk, and proximity of mining sites to escape terrain appear to encourage the use of some mining sites by wild sheep (Elliott and McKendrick 1984). Furthermore, increases in graminoid vegetation in reclaimed industrial lands could provide wild sheep with preferred forage (MacCullum and Geist 1992) given their forage preference toward graminoids year round (Seip and Bunnell 1985; Walker et al. 2007). Difficulties of restoring shrub habitats in harsh environments (Smyth 1997; Jorgenson et al. 2010; Sloan and Jacobs 2013) might discourage mountain goats from using reclaimed lands, especially in winter when their dependence on woody forage increases (Adams and Bailey 1983; Fox and Smith 1988). 
Landscape potentially considered for wind power development in northeast British Columbia occurs across elevations between 386 and $2114 \mathrm{~m}$, but most frequently in mid elevations between 732 and $1250 \mathrm{~m}$ (Online Resource 5: Table S5.1; Fig. S5.2). Unexpectedly, our analyses determined that the greatest overlap across seasons between highvalue habit and high wind power potential was for moose. The range of elevations and slope characteristics for high wind power potential most closely coincides with wintering habitats of moose in low-slope mid-elevation sparsely vegetated subalpine habitats (Gillingham and Parker 2008). As surmised, high-value habitats for caribou in winter (30\%) also occurred in areas with high wind potential. Gentle topography with space wide enough for wind power development coincides with habitats of caribou, particularly for individuals in low-slope high-elevation areas with low snow accumulation from constant exposure to wind (Johnson et al. 2004; Gustine and Parker 2008), for wintering elk that concentrate in large numbers on low-slope, lower-elevation areas with low snow accumulation (Gillingham and Parker 2008), and for wolves, which tend to occur in close proximity to their prey. Despite Stone's sheep and mountain goats being associated with open high-elevation areas, there was very little overlap between their high-value habitats and areas with high potential for wind power. If new roads and power lines associated with wind power generation are also considered, however, overall effects of wind power development on all of these wildlife species would be greater than from development of wind towers alone (Kuvlesky et al. 2007).

\section{Conservation and management implications}

We provided conservative assessments of conflict between areas of possible resource development and habitat conservation by restricting our analyses to distributions of only the high-value wildlife habitats and areas with high-resource potential. Using lower values of habitat suitability and/or resource potential would likely result in higher levels of conflict. Our assessments along with previous research (e.g., James et al. 2004; Seip 2008; Whittington et al. 2011; Beyer et al. 2013) lead us to conclude that resource development and the creation of networks of linear corridors such as roads, seismic lines, and pipelines in the Muskwa-Kechika may provide benefits to elk and moose through increases in early seral and/or edge habitats, and potentially to wolves through increases in these ungulates as prey. Caribou populations are likely to decline from losses of winter habitat (Smith et al. 2000; Courbin et al. 2009) and increases in predation by higher numbers of wolves that could result from higher numbers of elk and moose on disturbed landscapes (Serrouya et al. 2011; Boutin et al. 2012). Human activities and road access would likely reduce bear numbers (Ciarniello et al. 2007; Roever et al. 2008). Stone's sheep and mountain goats would probably be most affected by aerial disturbance, and as with all of the focal species, by loss of prime habitats. Consequently, the large-mammal assemblage and their interactions on the landscape will change with resource exploration and development in the Muskwa-Kechika. We recommend creating plans for the Muskwa-Kechika that will maintain the present abundance and diversity of wildlife populations. Land management should (1) minimize loss and fragmentation of late-successional forests, (2) prevent early seral habitats from substantially increasing and spreading across the Muskwa-Kechika, (3) avoid or minimize development of resources and associated infrastructures including roads, trails, seismic lines, and other linear features in high-value habitats of caribou, and (4) prevent or minimize development of new road access into high-value habitats of grizzly bears and near traditional areas of Stone's sheep and mountain goats. 
The GIS approach used here identifies and visually displays areas that overlap for wildlife conservation and industrial resource potential across a large geographic area. Using these resource potential layers along with habitat suitability maps, land managers and conservation scientists can (1) proactively establish conservation and/or management plans that would minimize future conflicts between habitat conservation and resource development in undeveloped landscapes such as the Muskwa-Kechika, (2) effectively discuss whether high conflict areas for particular species should be protected or whether some level of resource development might be allowed, depending on the overall area of a species' high-value habitat appropriated for conservation, and (3) simulate various scenarios on how resource development across space and time might affect the distribution and areas of high-value wildlife habitats or those of other land areas potentially designated for other purposes such as wilderness, outdoor recreation, or cultural heritage.

We have provided tangible baseline values of overlap between areas of resource potential and high-value wildlife habitats for a large landscape of almost intact wilderness. These baseline values also reveal probable conflicts between conservation of habitat and resource development, and are best applied in a framework of adaptive management - they should be continuously assessed and updated as new information becomes available. Having tangible baseline values makes it easier and more efficient to objectively compare and contrast new information to the baseline values and helps improve quality and validity of information incrementally over time. This process of assessment and discussion should encourage disclosure, sharing, and gathering of new information among scientists, resource managers, stakeholders, and the public. Our analyses provide a 'heads up' to those concerned with conservation of wildlife habitats and responsible resource management in the Muskwa-Kechika.

Acknowledgments We thank the following organizations for their contributions to this project: Round River Conservation Studies, Wildlife Infometrics, British Columbia Ministry of Forests, Lands, and Natural Resource Operations (FLNRO), GeoBC, and DataBC. Paul Jago at the BC Ministry of Energy and Mines, Jennifer Brooks at FLNRO, Scott Emmons at the University of Northern British Columbia, and Erik Meyer at the British Columbia Wildfire Management Branch helped us obtain much needed data for our analyses. We also thank reviewers for their feedback, which significantly improved the quality of our manuscript. This Project was funded by the Muskwa-Kechika Endowment at the University of Northern British Columbia, with support from the Muskwa-Kechika Advisory Board.

Open Access This article is distributed under the terms of the Creative Commons Attribution 4.0 International License (http://creativecommons.org/licenses/by/4.0/), which permits unrestricted use, distribution, and reproduction in any medium, provided you give appropriate credit to the original author(s) and the source, provide a link to the Creative Commons license, and indicate if changes were made.

\section{References}

Adams LG, Bailey JA (1983) Winter forages of mountain goats in central Colorado. J Wildl Manag 47:1237-1243

Andrew ME, Wulder MA, Coops NC (2012) Identification of de facto protected areas in boreal Canada. Biol Conserv 146:97-107

Andrew ME, Wulder MA, Cardille JA (2014) Protected areas in boreal Canada: a baseline and considerations for the continued development of a representative and effective reserve network. Environ Rev 22:135-160

Apps CD, McLellan BN, Woods JG, Proctor MF (2004) Grizzly bear distribution and abundance relative to habitat and human influence. J Wildl Manag 68:138-152

Badiou P, Baldwin R, Carlson M, Darveau M, Drapeau P, Gaston K, Jacobs J, Kerr J, Levin S, Manseau M, Orians G, Pimm S, Possingham H, Raven P, Reid F, Roberts D, Root T, Roulet N, Schaefer J, 
Schindler D, Strittholt J, Turner N, Wells J (2013) Conserving the world's last great forest is possible: here's how. A science/policy briefing note issued under the auspices of the International Boreal Conservation Science Panel and Associates. http://borealscience.org/wp-content/uploads/2013/07/ conserving-last-great-forests1.pdf. Accessed 23 Jan 2015

Beyer HL, Ung R, Murray DL, Fortin M (2013) Functional responses, seasonal variation and threshold in behavioural responses of moose to roads. J Appl Ecol 50:286-294

Boutin S, Boyce MS, Hebblewhite M, Hervieux D, Knopff KH, Latham MC, Latham DM, Nagy J, Seip D, Serrouya R (2012) Why are caribou declining in the oil sands? Front Ecol Environ 10:65-67

Bradshaw CJA, Boutin S, Hebert DM (1997) Effects of petroleum exploration on woodland caribou in northeastern Alberta. J Wildl Manag 61:1127-1133

Bradshaw CJA, Boutin S, Hebert DM (1998) Energetic implications of disturbance caused by petroleum exploration to woodland caribou. Can J Zool 76:1319-1324

Bright J, Langston R, Bullman R, Evans R, Gardner S, Pearce-Higgins J (2008) Map of bird sensitivities to wind farms in Scotland: a tool to aid planning and conservation. Biol Conserv 141:2342-2356

British Columbia Conservation Data Centre (2015) Caribou in British Columbia. British Columbia Ministry of Environment, Victoria. http://www.env.gov.bc.ca/wld/speciesconservation/. Accessed 15 May 2015

British Columbia Government (1999) Muskwa-Kechika Management Area Act. Queen's Printer, Victoria

British Columbia Ministry of Forests, Lands and Natural Resource Operations, Forest Analysis and Inventory Branch (2013) Vegetation resource inventory (VRI): forest vegetation composite polygons and rank 1 layer. http://www.for.gov.bc.ca/hts/vridata/. Accessed 10 Nov 2013. Currently available at: http://catalogue.data.gov.bc.ca/dataset/vri-forest-vegetation-composite-polygons-and-rank-1-layer

British Columbia Ministry of Sustainable Resource Management (2004) Pre-tenure plans for oil and gas development in the Muskwa-Kechika Management Area. British Columbia Ministry of Sustainable Resource Management, Victoria. https://www.for.gov.bc.ca/tasb/slrp/lrmp/fortstjohn/muskwa/pdf/ Recommended-final-May2004.pdf. Accessed 28 Jan 2014

Brodie J, Post E, Watson F, Berger J (2012) Climate change intensification of herbivore impacts on tree recruitment. Proc R Soc B 279:1366-1370

Carroll C, Noss RF, Paquet PC, Schumaker NH (2003) Use of population viability analysis and reserve selection algorithms in regional conservation plans. Ecol Appl 13:1773-1789

Carroll C, Noss RF, Paquet PC, Schumaker NH (2004) Debt of protected areas in developing landscapes. Conserv Biol 18:1110-1120

Christianson DA, Creel S (2007) A review of environmental factors affecting elk winter diets. J Wildl Manag 71:164-176

Ciarniello LM, Boyce MS, Heard DC, Seip DR (2007) Components of grizzly bear habitat selection: density, habitats, roads, and mortality risk. J Wildl Manag 71:1446-1457

Committee on the Status of Endangered Wildlife in Canada (2011) Designatable units for caribou (Rangifer tarandus) in Canada. Committee on the Status of Endangered Wildlife in Canada, Ottawa

Côté SD, Hamel S, St-Louis A, Mainguy J (2013) Do mountain goats habituate to helicopter disturbance? J Wildl Manag 77:1244-1248

Courbin N, Fortin D, Dussault C, Courtois R (2009) Landscape management for woodland caribou: the protection of forest blocks influences wolf-caribou co-occurrence. Landsc Ecol 24:1375-1388

Courbin N, Fortin D, Dussault C, Courtois R (2014) Logging-induced changes in habitat network connectivity shape behavioral interactions in the wolf-caribou-moose system. Ecol Monogr 84:265-285

Courtois R, Gingras A, Fortin D, Sebbane A, Rochette B, Breton L (2008) Demographic and behavioural response of woodland caribou to forest harvesting. Can J For Res 38:2837-2849

Dunne BM, Quinn MS (2009) Effectiveness of above-ground pipeline mitigation for moose (Alces alces) and other large mammals. Biol Conserv 142:332-343

Dussault C, Courtois R, Quellet J (2006) A habitat suitability index model to assess moose habitat selection at multiple spatial scales. Can J For Res 36:1097-1107

Dussault C, Pinard V, Ouellet JP, Courtois R, Fortin D (2012) Avoidance of roads and selection for recent cutovers by threatened caribou: fitness-rewarding or maladaptive behaviour? Proc R Soc B 279:4481-4488

Dyer SJ, O’Neill JP, Wasel SM, Boutin S (2001) Avoidance of industrial development by woodland caribou. J Wildl Manag 65:531-542

Ehlers LPW, Johnson C, Seip DR (2014) Movement ecology of wolves across an industrial landscape supporting threatened populations of woodland caribou. Landsc Ecol 29:451-465

Elliott CL, McKendrick JD (1984) Food habits of Dall sheep on revegetated coal stripmine spoils in Alaska. In: Proceedings of the fourth biennial symposium of the Northern Wild Sheep and Goat Council, vol 4, p 241-251 
Epps CW, Palsbøll PJ, Wehausen JD, Roderick GK, Ramey RR, McCullough DR (2005) Highways block gene flow and cause a rapid decline in genetic diversity of desert bighorn sheep. Ecol Lett 8:1029-1038

ESRI (2011) ArcGIS desktop: release 10. Environmental Systems Research Institute, Redlands

Faille G, Dussault C, Ouellet J-P, Fortin D, Courtois R, St-Laurent M-H, Dussault C (2010) Range fidelity: the missing link between caribou decline and habitat alteration? Biol Conserv 143:2840-2850

Fort Nelson LRMP Working Group (1997) Fort Nelson land and resource management plan. British Columbia Land Use Coordination Office, Victoria

Fort St. John LRMP Working Group (1997) Fort St. John land and resource management plan. British Columbia Land Use Coordination Office, Victoria

Fox JL, Smith CA (1988) Winter mountain goat diets in southeast Alaska. J Wildl Manag 52:362-365

Frid A (2003) Dall's sheep responses to overflights by helicopter and fixed-wing aircraft. Biol Conserv 110:387-399

Geldmann J, Joppa LN, Burgess ND (2014) Mapping change in human pressure globally on land and within protected areas. Conserv Biol 6:1-13

Gillingham MP, Parker KL (2008) Differential habitat selection by moose and elk in the Besa-Prophet Area of northern British Columbia. Alces 44:41-63

Gustine DD, Parker KL (2008) Variation in seasonal selection of resources by woodland caribou in northern British Columbia. Can J Zool 86:812-825

Heinemeyer K, Tingey R, Ciruna K, Lind T, Pollock J, Butterfield B, Griggs J, Lachetti P, Bode C, Olenicki T, Parkinson E, Rumsey C, Sizemore D (2004) Conservation area design for the Muskwa-Kechika Management Area. British Columbia Ministry of Sustainable Resource Management. http://www. roundriver.org/wpontent/uploads/pubs/MK/reports/MK_CAD_V1.pdf. Accessed 11 Dec 2014

Hins C, Ouellet J-P, Dussault C, St-Laurent M-H (2009) Habitat selection by forest-dwelling caribou in managed boreal forest of eastern Canada: evidence of a landscape configuration effect. For Ecol Manag 257:636-643

Houle M, Fortin D, Dussault C, Courtois R, Ouellet J (2010) Cumulative effects of forestry on habitat use by gray wolf (Canis lupus) in the boreal forest. Landsc Ecol 25:419-433

Irwin LL, Peek JM (1983) Elk habitat use relative to forest succession in Idaho. J Wildl Manag 47:664-672

James ARC, Stuart-Smith K (2000) Distribution of caribou and wolves in relation to linear corridors. J Wildl Manag 64(1):154-159

James ARC, Boutin S, Rippin AB (2004) Spatial separation of caribou from moose and its relation to predation by wolves. J Wildl Manag 68:799-809

Jansen BD, Krausman PR, Heffelfinger JR, deVos JC Jr (2006) Bighorn sheep selection of landscape features in an active copper mine. Wildl Soc Bull 34:1121-1126

Jansen BD, Krausman PR, Heffelfinger JR, deVos JC Jr (2007) Influence of mining on behavior of bighorn sheep. Southwest Nat 52:418-423

Jenkins KJ, Starkey EE (1993) Winter forages and diets of elk in old-growth and regenerating coniferous forests in western Washington. Am Midl Nat 130:299-313

Johnson CJ, Parker KL, Heard DC, Gillingham MP (2002) A multiscale behavioral approach to understanding the movements of woodland caribou. Ecol Appl 12:1840-1860

Johnson CJ, Parker KL, Heard DC, Seip DR (2004) Movements, foraging habits, and habitat use strategies of northern woodland caribou during winter: implications for forest practices in British Columbia. BC J Ecosyst Manag 5:22-35

Joly K, Nellemann C, Vistnes I (2006) A reevaluation of caribou distribution near an oilfield road on Alaska's north slope. Wildl Soc Bull 34:866-869

Jorgenson JC, Ver Hoef JM, Jorgenson MT (2010) Long-term recovery patterns of Arctic tundra after winter seismic exploration. Ecol Appl 20:205-221

Komers PE, Stanojevic J (2013) Rates of disturbance vary by data resolution: implications for conservation schedules using the Alberta Boreal Forest as a case study. Glob Change Biol 19:2916-2928

Kreutzweiser D, Beall F, Webster K, Thompson D, Creed I (2013) Impacts and prognosis of natural resource development on aquatic biodiversity in Canada's boreal zone. Environ Rev 21(2013):227-259

Kuvlesky WP Jr, Brennan LA, Morrison ML, Boydston KK, Ballard BM, Bryant FC (2007) Wind energy development and wildlife conservation: challenges and opportunities. J Wildl Manag 71:2487-2498

Latham ADM, Latham MC, Boyce MS, Boutin S (2011) Movement responses by wolves to industrial linear features and their effect on woodland caribou in northeastern Alberta. Ecol Appl 21:2854-2865

Leclerc M, Dussault C, St-Laurent M (2012a) Multiscale assessment of the impacts of roads and cutovers on calving site selection in woodland caribou. For Ecol Manag 286:59-65

Leclerc M, Lamoureux J, St-Laurent M (2012b) Influence of young black spruce plantations on moose winter distribution. J Wildl Manag 76:1686-1693 
Leclerc M, Dussault C, St-Laurent M (2014) Behavioural strategies towards human disturbances explain individual performance in woodland caribou. Oecologia 176:297-306

Leroux SJ, Kerr JT (2013) Land development in and around protected areas at the wilderness frontier. Conserv Biol 27:166-176

Lesmerises R, Ouellet J-P, Dussault C, St-Laurent M-H (2013) The influence of landscape matrix on isolated patch use by wide-ranging animals: conservation lessons for woodland caribou. Ecol Evol 3:2880-2891

Linke J, Franklin SE, Huettmann F, Stenhouse GB (2005) Seismic cutlines, changing landscape metrics and grizzly bear landscape use in Alberta. Landsc Ecol 20:811-826

Linnell JDC, Swenson JE, Andersen R, Barnes B (2000) How vulnerable are denning bears to disturbance? Wildl Soc Bull 28:400-413

Locke H (2010) Yellowstone to Yukon connectivity conservation initiative. In: Worboys GL, Francis WL, Lockwood M (eds) Connectivity conservation management: a global guide. Taylor and Francis, New York, pp 161-181

Lovich JE, Ennen JR (2011) Wildlife conservation and solar energy development in the desert southwest, United States. Bioscience 61:982-992

MacCullum BN, Geist B (1992) Mountain restoration: soil and surface wildlife habitat. GeoJournal 27:23-46

Mackenzie LRMP Working Group (2000) Mackenzie land and resource management plan. British Columbia Land Use Coordination Office, Victoria

Magurran AE (1988) Ecological diversity and its measurement. Princeton University Press, Princeton

McCorquodale SM, Wiseman R, Marcum CL (2003) Survival and harvest vulnerability of elk in the Cascade Range of Washington. J Wildl Manag 67:248-257

McKay T, Sahlén E, Støen O-G, Swenson JE, Stenhouse GB (2014) Wellsite selection by grizzly bears Ursus arctos in west-central Alberta. Wildl Biol 20:310-319

McLellan BN (2015) Some mechanisms underlying variation in vital rates of grizzly bears on a multiple use landscape. J Wildl Manag 79:749-765

McLoughlin PD, Dzus E, Wynes B, Boutin S (2003) Declines in populations of woodland caribou. J Wildl Manag 67:755-761

Milakovic B, Parker KL, Gustine DD, Lay RJ, Walker ABD, Gillingham MP (2011) Habitat selection by a focal predator in a multiprey ecosystem of the northern Rockies. J Mammal 92:568-582

Milakovic B, Parker KL, Gustine DD, Lay RJ, Walker ABD, Gillingham MP (2012) Seasonal habitat use and selection by grizzly bears in northern British Columbia. J Wildl Manag 76:170-180

Morgantini LE, Bruns E (1988) Attraction of bighorn sheep to wellsites and other man-made mineral licks along the eastern slopes of Alberta: a management concern. In: Proceedings of the sixth biennial symposium of the Northern Wild Sheep and Goat Council, vol 6, p 135-140

Morgantini LE, Worbets BW (1988) Bighorn sheep use of a gas wellsite during servicing and testing: a case study of impact and mitigation. In: Proceedings of the sixth biennial symposium of the Northern Wild Sheep and Goat Council, vol 6, p 159-164

Muir BR, Booth AL (2012) An environmental justice analysis of caribou recovery planning, protection of an indigenous culture, and coal mining development in northeast British Columbia, Canada. Environ Dev Sustain 14:455-476

Munõz-Fuentes V, Darimont CT, Wayne RK, Paquet PC, Leonard JA (2009) Ecological factors drive differentiation in wolves from British Columbia. J Biogeogr 36:1516-1531

Muskwa-Kechika Management Area (2014) Resource Management zones. http://www.muskwa-kechika. com/management-area/resource-management-zones. Accessed 5 May 2014

Nitschke CR (2008) The cumulative effects of resource development on biodiversity and ecological integrity in the Peace-Moberly region of Northeast British Columbia, Canada. Biodivers Conserv $17: 1715-1740$

Pearce JL, Kirk DA, Lane CP, Mahr MH, Walmsley J, Casey D, Muir JE, Hannon S, Hansen A, Jones K (2008) Prioritizing avian conservation areas for the Yellowstone to Yukon region of North America. Biol Conserv 141:908-924

Person DK, Russell AL (2008) Correlates of mortality in an exploited wolf population. J Wildl Manag 72:1540-1549

Pigeon KE, Nielsen SE, Stenhouse GB, Côté SD (2014) Den selection by grizzly bears on a managed landscape. J Mammal 95:559-571

Polfus JL, Hebblewhite M, Heinemeyer K (2011) Identifying indirect habitat loss and avoidance of human infrastructure by northern mountain woodland caribou. Biol Conserv 144:2637-2646

Poole KG, Mowat G (2005) Winter habitat relationships of deer and elk in the temperate interior mountains of British Columbia. Wildl Soc Bull 33:1288-1302 
Poole KG, Bachmann KD, Teske IE (2010) Mineral lick use by GPS radio-collared mountain goats in southeastern British Columbia. West N Am Nat 70:208-217

Potvin F, Breton L, Courtois R (2005) Response of beaver, moose, and snowshoe hare to clear-cutting in a Quebec boreal forest: reassessment 10 years after cut. Can J For Res 35:151-160

Proulx G, Kariz RM (2005) Winter habitat use by moose, Alces alces, in central interior British Columbia. Can Field Nat 119:186-191

Rempel RS, Elkie PC, Rodgers AR, Gluck MJ (1997) Timber-management and natural-disturbance effects on moose habitat: landscape evaluation. J Wildl Manag 61:517-524

Roever CL, Boyce MS, Stenhouse GB (2008) Grizzly bears and forestry II: grizzly bear habitat selection and conflicts with road placement. For Ecol Manag 256:1262-1269

Roscioni F, Russo D, Di Febbraro M, Frate L, Carranza ML, Loy A (2013) Regional-scale modelling of the cumulative impact of wind farms on bats. Biodivers Conserv 22:1821-1835

Rumble MA, Gamo RS (2011) Habitat use by elk (Cervus elaphus) within structural stages of a managed forest of the northcentral United States. For Ecol Manag 261:958-964

Schneider RR, Wasel S (2000) The effect of human settlement on the density of moose in Northern Alberta. J Wildl Manag 64:513-520

Schneider RR, Stelfox JB, Boutin S, Wasel S (2003) Managing the cumulative impacts of land-uses in the western Canadian sedimentary basin: a modeling approach. Conserv Ecol 7:8. http://www.consecol. org/vol7/iss1/art8/. Accessed 28 Jan 2015

Schneider RR, Hauer G, Adamowicz WLV, Boutin S (2010) Triage for conserving populations of threatened species: the case of woodland caribou in Alberta. Biol Conserv 143:1603-1611

Seip DR (1992) Factors limiting woodland caribou populations and their interrelationship with wolves and moose in southeastern British Columbia. Can J Zool 70:1494-1503

Seip DR (1998) Ecosystem management and the conservation of caribou habitat in British Columbia. Rangifer Spec Issue 10:203-212

Seip DR (2008) Mountain caribou interactions with wolves and moose in central British Columbia. Alces 44:1-5

Seip DR, Bunnell FL (1985) Nutrition of Stone's sheep on burned and unburned ranges. J Wildl Manag 49:397-405

Serrouya R, McLellan BN, Boutin S, Seip DR, Nielsen SE (2011) Developing a population target for an overabundant ungulate for ecosystem restoration. J Appl Ecol 48:935-942

Shultis J, Rutledge R (2003) The Muskwa-Kechika Management Area, a model for the sustainable development of wilderness? Int J Wilderness 9:12-17

Sloan JL, Jacobs DF (2013) Fertilization at planting influences seedling growth and vegetative competition on a post-mining boreal reclamation site. N For 44:687-701

Smith KG, Janet FE, Hobson D, Sorensen TC, Hervieux D (2000) Winter distribution of woodland caribou in relation to clear-cut logging in west-central Alberta. Can J Zool 78(8):1433-1440

Smyth CR (1997) Early succession patterns with a native species seed mix on amended and unamended coal mine spoil in the Rocky Mountains of southeastern British Columbia, Canada. Arct Alp Res 29:184-195

Snively M, Brumovsky VJ (2011) Investigating potential impacts of wind power development in the M-KMA - physical feasibility model methods and spatial data summary. Wildlife Infometrics, Inc. Report No. 367. Wildlife Infometrics, Inc., Mackenzie

Sorensen T, McLoughlin PD, Hervieux D, Dzus E, Nolan J, Wynes B, Boutin S (2008) Determining sustainable levels of cumulative effects for boreal caribou. J Wildl Manag 72:900-905

Stewart A, Komers PE, Bender DJ (2010) Assessing landscape relationships for habitat generalists. Ecoscience 17:28-36

Stewart BP, Nelson TA, Wulder MA, Nielsen SE, Stenhouse G (2012) Impact of disturbance characteristics and age on grizzly bear habitat selection. Appl Geogr 34:614-625

Strimbu B, Innes J (2011) An analytical platform for cumulative impact assessment based on multiple futures: the impact of petroleum drilling and forest harvesting on moose (Alces alces) and marten (Martes americana) habitats in northeastern British Columbia. J Environ Manag 92:1740-1752

Stronen AV, Paquet P, Herrero S, Sharpe S, Waters N (2007) Translocation and recovery efforts for the Telkwa Caribou, Rangifer tarandus caribou, herd in westcentral British Columbia, 1997-2005. Can Field Nat 121:155-163

Unsworth JW, Kuck L, Scott MD, Garton EO (1993) Elk mortality in the Clearwater drainage of northcentral Idaho. J Wildl Manag 57:495-502

Van Dyke F, Fox A, Harju SM, Dzialak MR, Hayden-Wing LD, Winstead JB (2012) Response of elk to habitat modification near natural gas development. Environ Manag 50:942-955 
Venier LA, Thompson ID, Fleming R, Malcolm J, Aubin I, Trofymow JA, Langor D, Sturrock R, Patry C, Outerbridge RO, Holmes SB, Haeussler S, De Grandpré L, Chen HYH, Bayne E, Arsenault A, Brandt JP (2014) Effects of natural resource development on the terrestrial biodiversity of Canadian boreal forests. Environ Rev 22:457-490

Visscher DR, Merrill EH (2009) Temporal dynamics of forage succession for elk at two scales: implications of forest management. For Ecol Manag 257:96-106

Vors LS, Schaefer JA, Pond BA, Rodgers AR, Patterson BR (2007) Woodland caribou extirpation and anthropogenic landscape disturbance in Ontario. J Wildl Manag 71:1249-1256

Walker ABD, Parker KL, Gillingham MP, Gustine DD, Lay RJ (2007) Habitat selection by female Stone's sheep in relation to vegetation, topography, and risk of predation. Ecoscience 14:55-70

Webb SL, Dzialak MR, Wondzell JJ, Harju SM, Hayden-Wing LD, Winstead JB (2011) Survival and causespecific mortality of female Rocky Mountain elk exposed to human activity. Popul Ecol 53:483-493

Weir JN, Mahoney SP, McLaren B, Ferguson SH (2007) Effects of mine development on woodland caribou Rangifer tarandus distribution. Wildl Biol 13:66-74

Wells JV, Reid F, Darveau M, Childs D (2013) Ten cool Canadian biodiversity hotspots: how a new understanding of biodiversity underscores the global significance of Canada's boreal forest. Boreal Songbird Initiative, Ducks Unlimited, Inc., and Ducks Unlimited Canada, Seattle

Whittington J, Hebblewhite M, DeCesare NJ, Neufeld L, Bradley M, Wilmshurst J, Musiani M (2011) Caribou encounters with wolves increase near roads and trails: a time-to-event approach. J Appl Ecol 48:1535-1542

Wittemyer G, Elsen P, Bean WT, Burton ACO, Brashares JS (2008) Accelerated human population growth at protected area edges. Science 321:123-126

Wittmer HU, Mclellan BN, Serrouya R, Apps CD (2007) Changes in landscape composition influence the decline of a threatened woodland caribou population. J Anim Ecol 76:568-579 